OPEN ACCESS

Edited by:

Ranjan Kumar Ghosh, Indian Institute of Management Ahmedabad, India

Reviewed by: Pablo Imbach, Global Center on Adaptation, Netherlands

Srinivasa Reddy Srigiri,

Deutsches Institut für Entwicklungspolitik (DIE), Germany

*Correspondence: Anil Markandya anil.markandya@bc3research.org

Specialty section: This article was submitted to Environmental Economics and Management

a section of the journa Frontiers in Environmental Science

Received: 01 March 2021 Accepted: 18 June 2021 Published: 06 July 2021

Citation: Markandya A, Salcone J, Hussain S, Mueller A and Thambi S (2021) Covid, the Environment and Food Systems:

Contain, Cope and Rebuild Better.

Front. Environ. Sci. 9:674432.

doi: 10.3389/fenvs.2021.674432

\section{Covid, the Environment and Food Systems: Contain, Cope and Rebuild Better}

\author{
Anil Markandya ${ }^{1 *}$, Jacob Salcone ${ }^{2}$, Salman Hussain ${ }^{2}$, Alexander Mueller $^{3}$ and Simi Thambi ${ }^{2}$ \\ ${ }^{1}$ Basque Centre for Climate Change, Leioa, Spain, ${ }^{2}$ UNEP - Ecosystem Service Economics Unit, Nairobi, Kenya, ${ }^{3} T M G$ - Think \\ Tank for Sustainability, Berlin, Germany
}

The objective of this paper is to analyse impacts of COVID-19 on the nexus of food systems, the environment and sustainable development and propose ways for governments and international agencies to mitigate impacts in the short and medium term. It covers the historic period from early 2020 to early 2021 and also makes an assessment on future prospects. Although evidence is collected from all around the world, the focus is primarily on developing countries. The methods used are a review of the announced actions and preliminary findings in the academic and grey literature as well as on reliable websites from global and international institutions. By October 2020, governments around the world had invested about $\$ 12$ trillion to counteract the economic effects of COVID-19. This investment could contribute to progress on the SDGs and global climate targets insofar as it was invested within a framework that supports both socio-economic recovery and sustainability. Initial analysis indicates that investments for economic recovery did not sufficiently address food security and sustainability, concentrating instead on immediate economic risk management. The global sustainable development agenda must promote the resilience and sustainability of food systems through policies and measures that: i) account for environmental thresholds and trade-offs; ii) promote food security and healthy diets; iii) enhance and protect rural livelihoods; and iv) address the inequalities and injustices that have emerged and will prevail during a post-COVID transition. National stimulus programs and the actions of international agencies must be assessed and monitored to deliver multiple benefits simultaneously and guide building back better.

Keywords: COVID-19, food systems, environment, pollution, rebuild

\section{INTRODUCTION}

COVID-19 presents an unprecedented global health and economic crisis. Since detection of the virus at the end of 2019, it has caused around 157 million infections and more than 3.3 million deaths. ${ }^{1}$ All around the world, millions of people have lost jobs and income in the deepest economic downturn in living memory. The health impacts include both the direct consequences of infection and the effects

${ }^{1}$ WHO Coronavirus Disease (COVID-19) Dashboard | WHO Coronavirus Disease (COVID-19) Dashboard, Accessed May 10th' 2021 
of measures taken to contain the outbreak, such as increased poverty, hunger, undernutrition and social disruption. These have not yet been fully understood or quantified. ${ }^{2}$ It is clear, however, from the material reviewed in this paper, that the combination of economic and health effects is still impacting and will continue to impact the environment. While there are some positive impacts, the majority are negative. Moreover, it is curtailing the prospects for achieving the Sustainable Development Goals (SDGs).

This article analyses the effects of COVID-19 on all aspects of the environment, with a focus on interconnections between the pandemic and the agri-food system and considers how these effects are best mitigated. The findings are highly relevant to the continued response to the pandemic, as well as to prevention of similar crises in the future.

Prior to COVID-19, the case for systemic change in food systems was gathering momentum as countries, the United Nations, and academia drew attention to the role such systems played-both positive and negative-in achieving the SDGs. More than any other sector, the agri-food system entails a web of feedbacks between ecosystems, livelihoods, economic development, trade relations and human health. This means it can support or hinder progress towards many of the 17 SDGs, such as Zero Hunger (SDG 2), Good Health and Well-Being (SDG 3), Gender Equality (SDG 5), Decent Work and Economic Growth (SDG 8) and Climate Action (SDG 13). Food production is a leading driver of biodiversity loss and a major contributor to GHG emissions (PBL Netherlands Environmental Assessment Agency, 2014; Mbow et al., 2019). The food and agriculture sector employs over a billion people world-wide (Food and Agriculture Organization of the United Nations, 2016, p. 18). Food systems are the backbone of human health but also contribute to some of the fastest growing health problems-non-communicable diseases (NCDs) such as diabetes, obesity related cancers and heart disease (World Cancer Research Fund International, 2014; Anand et al., 2015; Food and Agriculture Organization of the United Nations, 2016).

The article is structured as follows. Macroeconomic Impacts of the COVID19 Crises lays out the socioeconomic impacts of COVID-19, as well the broad economic impacts measures that alleviate the negative effects of the pandemic. It examines the implications for the food system and food security outcomes. The impacts of the pandemic on the environment and natural systems are evaluated in Impacts of COVID-19 on the Nexus Between Agri-Food Systems and the Environment. Coping Strategies and Their Impacts looks in detail at what governments are doing in their responses and how these affect the agri-food system as well as the environment. Lessons From Coping With COVID-19 and the Way Forward describes what has been learnt so far from government responses and makes recommendations for actions in the short and the medium term. Overall conclusions are in Conclusion.

${ }^{2} \mathrm{~A}$ first overview of impacts based on household surveys can be found at https:// advances.sciencemag.org/content/7/6/eabe0997

\section{MACROECONOMIC IMPACTS OF THE COVID19 CRISES}

\section{Impacts on GDP Growth and Other Indicators}

The negative economic effects of COVID-19 and the measures taken to fight the pandemic have both been enormous. Preliminary estimates by the IMF for 2020 are that a decline in global GDP of 3.5 percent has taken place (International Monetary Fund, 2020b). Such a decline is unprecedented in the postwar period and has had major impacts on poverty, hunger and other key indicators of wellbeing. A recovery is projected for 2021 and 2022, but with exceptional levels of uncertainty, especially given the persistence of infection rates and emergence of new variants of the virus. Even if these challenges are overcome the consequences of COVID-19 will remain for some time. As the World Bank notes, “... beyond its short-term impact, deep recessions triggered by the pandemic are likely to leave lasting scars through multiple channels, including lower investment; erosion of the human capital of the unemployed; and a retreat from global trade and supply linkages. These effects may lower potential growth and labour productivity in the longer term" (World Bank, 2020a, p. xvl). A computable general equilibrium (CGE) model developed to assess the impact of the pandemic in sub-Saharan Africa based on past experiences of similar crises (notably the 2014 Western Africa Ebola crisis) has found that COVID-19 is likely to have a lasting impact on labour productivity due to its adverse effect on human capital and infrastructure (Djiofack et al., 2020). In the best case, with the disease rapidly contained, the authors estimate the GDP of Africa will be permanently 1 per cent lower than without the pandemic; in the catastrophic scenario, where the crisis lasts more than 18 months, it will be 4 per cent lower for more than a decade. Other studies show that budgets for health have not increased enough to maintain services, especially for the poorer sections of the population across a range of countries (Dash et al., 2020) and there has been a loss of human capital. These effects, however, will vary across regions and the findings for Africa may not apply elsewhere.

\section{Poverty and Hunger}

Estimates of people being pulled into poverty vary depending on the poverty line used. They are in the range of 71-100 million for extreme poverty (a poverty line of $\$ 1.9$ per day) (International Bank for Reconstruction and Development and World Bank, 2020). This implies that global extreme poverty would have increased from 8.2 per cent in 2019 to 8.8 per cent under the baseline scenario (where the decline in GDP is the middle of the projected range) and to 9.2 per cent under the downside (or pessimistic) scenario, where the GDP decline is at the lower end of the range of estimates for 2020. It would be the first increase in global extreme poverty since 1998 and would effectively wipe out progress made since 2017. Even before the pandemic, it was increasingly unlikely that the SDG of reducing extreme poverty to 3 per cent of the global population over the next decade would be achieved (World Bank, 2018). The pandemic puts this goal out of 
reach. Household incomes are expected to be weighed down by a sharp reduction in employment opportunities, lost earnings due to illness and the fall in remittances (Gupta et al., 2020; Caruso et al., 2021; Chowdhury and Chakraborty, 2021).

At the same time, many people are unable to feed themselves adequately. The World Food Programme (WFP) estimated the number of people suffering from acute hunger throughout the world would double from 135 million at present to 265 million by the end of 2020 (World Food Programme, 2020). Children are particularly vulnerable to a lack of adequate nutrition. An analysis by Lancet found that as many as 6.5 million more children under 5 years of age could suffer from wasting (low weight relative to their height) during the first year of the pandemic, an increase of 14.3 per cent. Without appropriate action being taken, this could result in an additional 10,000 deaths per month (Headey et al., 2020). UNICEF has an online dashboard that collates data from 159 countries to show their performance for different child welfare parameters. It shows that most countries in the low or lower middle income category have experienced drops in nutrition programmes for adolescent girls and boys, as well as in nutrition programmes for schoolchildren (United Nations Children's Fund, 2020). There are also vulnerable groups in developed countries that are facing unprecedented food insecurity, even in the world's wealthiest cities, such as Geneva (Patrick, 2020). A report by Oxfam estimates that there could be more deaths from hunger than from COVID-19 (Oxfam Australia, 2020).

A report by the Food and Agriculture Organization of the United Nations (FAO) highlights that as guardians of household food security, women are also disproportionately affected by the impacts of the pandemic. In most countries, women lead agriculture and related activities, which makes them more vulnerable to the pandemic than men. There is evidence of this phenomenon in previous epidemics, such as Ebola and Middle East Respiratory Syndrome. These diseases have the potential to seriously undermine the empowerment of these women, making gender-disaggregated data, gender-sensitive social security nets and awareness of the gender impact of policy responses vital (Food and Agriculture Organization of the United Nations, 2020c).

\section{Food Prices and Food Security}

Average food prices rose modestly in 2020: for 2020 as a whole the FAO food price index was 3.1 percent higher than in $2019 .{ }^{3}$ Projections by FAO and other agencies are varied but we are beginning to see the global repercussions of disrupted agricultural production during 2020. The FAO food price monitor showed distressing increases in January and February 2021. This global picture also contains severe local price increases in a number of locations. The International Food Policy Research Institute (IFPRI) has launched a COVID-19 food price

${ }^{3}$ FAO Food Price Index | World Food Situation | Food and Agriculture Organization of the United Nations monitor that tracks pressure on food prices showed mostly downward trends in 2020, but with some exceptions (Food Security Portal, 2020). For example, last year potato prices in India increased more than 15 per cent and rice prices have also risen in some markets. In Uganda, prices of maize, millet and wheat have gone up more than 15 per cent and some commodity prices have increased in Rwanda and Burundi as well, the two other countries in Africa that are monitored. A long term view of food price movements, however, shows periodic cycles with significant increases followed by declines. The current movements would not stand out in this long run picture. ${ }^{4}$

A number of factors have been identified as the causes of local price rises. Some supply chains are being negatively impacted by a lack of workers and transportation, such as meat processing (Schmidhuber et al., 2020) and dairy (Minten et al., 2020). There are reports that prohibitions on the migration of seasonal farm workers are also impacting crop prices (Gonzalez and Aronczyk, 2020; Schmidhuber and Qiao, 2020). In some places, global supply chains (i.e., the different stages in taking a food item from the grower to the consumer) have broken down and while local supply chains are reorganizing to accommodate this phenomenon, there has been upward pressure on prices in some cases (The Economist, 2020; Food and Agriculture Organization of the United Nations, 2020f). Furthermore, as of April 2020, 17 countries had introduced export restrictions on food items (World Trade Organization, 2020a). While these are a relatively small number compared to previous crises, they nonetheless impact food prices locally, particularly in countries heavily dependent on food imports, such as the small island developing states (Tableau Public, 2020). ${ }^{5}$ The same was observed in previous periods when a decline in production of a food commodity is followed by export restrictions, raising prices internationally (Espitia et al., 2020).

In 2020, the problem in most countries was not a food security crisis induced by food prices going up but rather incomes going down (Schmidhuber et al., 2020). The increase in unemployment and poverty referred to above reduces spending on food and raises the level of hunger and undernutrition. At the same time, there are warnings that supply factors could worsen due to falling investment, labour shortages and other aspects of supply chain logistics (Goel et al., 2020). The spread of COVID-19 in slaughterhouses-not from meat itself but from the working and living conditions-is particularly important (Science Media Centre, 2020). More generally, restrictions on movement enacted to prevent the spread of the virus are starting to disrupt the supply of agri-food products to markets and consumers, both within and across borders (Organisation for

\footnotetext{
${ }^{4}$ Food Prices - Our World in Data

${ }^{5}$ According to IFPRI, during the crisis of 2007-08 export restrictions blocked about 11 per cent of the calories that flowed through global markets. In this pandemic similar measures have affected only 3 per cent of supplies but there are signs that the number is going up. See: http://sdg.iisd.org/commentary/guest-articles/covid19-measures-in-spotlight-at-wto-meeting-on-agriculture/.
} 
TABLE 1 | COVID-19 related impacts on food systems and nature.

\begin{tabular}{|c|c|c|c|}
\hline & Ecosystems and biodiversity & Pollution & Climate change \\
\hline \multirow[t]{5}{*}{$\begin{array}{l}\text { Economic } \\
\text { impacts }\end{array}$} & $\begin{array}{l}\text { Less funds for enforcement: evidence of increase in } \\
\text { poaching, fly tipping, etc. (-) }\end{array}$ & $\begin{array}{l}\text { Less funds to ensure compliance with waste } \\
\text { disposal and agrichemical use }(-)\end{array}$ & $\begin{array}{l}\text { Less funds to ensure compliance on climate- } \\
\text { smart agriculture (-) }\end{array}$ \\
\hline & $\begin{array}{l}\text { Falling incomes reduce pressure on commercial } \\
\text { capture fisheries }(+)\end{array}$ & $\begin{array}{l}\text { Lower prices for inputs such as fertilizer, but may } \\
\text { lead to overuse }(+/-)\end{array}$ & $\begin{array}{l}\text { Less biofuel demand lowering forest } \\
\text { clearance- related emissions }(+)\end{array}$ \\
\hline & $\begin{array}{l}\text { Unemployment increases pressure on subsistence } \\
\text { fisheries and wild food harvesting (-) }\end{array}$ & $\begin{array}{l}\text { Less work absenteeism due to lower local } \\
\text { pollutants }(+)\end{array}$ & $\begin{array}{l}\text { More land clearance to increase provision of } \\
\text { food as a result of higher self-sufficiency (-) }\end{array}$ \\
\hline & $\begin{array}{l}\text { Less biofuel demand reduces pressure for forest } \\
\text { clearance and habitat loss (+) }\end{array}$ & & Lower emissions due to lower activity (+) \\
\hline & $\begin{array}{l}\text { More land clearing to increase provision of food to } \\
\text { replace wild meat in some places but more hunting } \\
\text { of wildlife in others }(+/-)\end{array}$ & & $\begin{array}{l}\text { Emissions impacts during recovery phase } \\
\text { depend on nature of fiscal stimulus (+/-) }\end{array}$ \\
\hline \multirow{4}{*}{$\begin{array}{l}\text { Health-related } \\
\text { impacts }\end{array}$} & Diet shifts due to lower incomes (?) & Diet shifts due to lower incomes (?) & Diet shifts due to lower incomes (?) \\
\hline & $\begin{array}{l}\text { Labour shortages reduce crop and livestock } \\
\text { productivity, reducing food availability (-) }\end{array}$ & $\begin{array}{l}\text { Higher mortality rates from COVID-19 in areas } \\
\text { where pollution levels are high (-); but lower } \\
\text { pollution levels due to lower activity (+) }\end{array}$ & $\begin{array}{l}\text { Lasting shift in production and consumption } \\
\text { patterns (?) }\end{array}$ \\
\hline & Less human resources to manage land (-) & $\begin{array}{l}\text { Indoor air pollution worsens as people, primarily } \\
\text { women and children, spend more time indoors (-) }\end{array}$ & \\
\hline & $\begin{array}{l}\text { Greater control of use of wildlife in some places }(+) \text {; } \\
\text { less control and more use in others }(-)\end{array}$ & $\begin{array}{l}\text { Restrictions on movement making access to } \\
\text { sanitation and safe water difficult }(-)\end{array}$ & \\
\hline Social impacts & $\begin{array}{l}\text { Increased pressure on common resources as } \\
\text { workers return from urban areas and from } \\
\text { overseas (-) } \\
\text { Increased pressure on land as workers return from } \\
\text { urban areas and from overseas (-) }\end{array}$ & $\begin{array}{l}\text { Possibility of changing use of transport for work } \\
\text { and social reasons over the long term with lower } \\
\text { local air emissions (+) }\end{array}$ & $\begin{array}{l}\text { Lower GHG emissions under travel } \\
\text { restrictions (+); higher emissions due to } \\
\text { reduced mass-transit use (-) } \\
\text { Possible long-term changes in travel/ } \\
\text { transport for all uses, with lower GHG } \\
\text { emissions (+) }\end{array}$ \\
\hline
\end{tabular}

Economic Co-operation and Development, 2020b; Nandi et al., 2021). ${ }^{6}$ How this impacts the wider community will depend on national policy responses. The FAO food price index reported a 4.3 percent global average increase in January, 2021. Rising food prices in 2021 could compound with income loss to create a food security crisis.

\section{IMPACTS OF COVID-19 ON THE NEXUS BETWEEN AGRI-FOOD SYSTEMS AND THE ENVIRONMENT}

The economic, health and social impacts of COVID-19 have direct and indirect links to the natural environment and to the way agri-food systems are organized. The UNEP COVID-19 updates list a number of impacts on the environment (https:// www.unep.org/covid-19); this section summarizes these impacts and highlights linkages to food systems. The updates also discuss opportunities to mitigate climate change and new risks arising from the pandemic with the potential to accelerate climate change. Similarly, they draw attention to the role of habitat destruction on the propagation of zoonotic diseases such as COVID-19 and the threat facing agriculture sectors, such as rice production, which are being further damaged by the effects of the pandemic.

${ }^{6}$ Real time reports on the impacts of Covid19 and the measures against the pandemic on the everyday life of people are presented on Twitter $@$ CovidFoodFuture or on Medium https://link.medium.com/VkoF73QRRdb
Table 1 provides a list of key ways in which food systems and nature are being affected by COVID-19 and the measures taken to contain it. It groups impacts according to UNEP's three areas for strategic action: ecosystems and biodiversity; pollution; and climate change. The main channels by which these categories are impacted are through the economic, health and social effects of COVID-19. Many environmental impacts-both positive and negative-are related to the economic contraction: on the one hand, less economic activity may reduce pollution and emissions; on the other, shrinking budgets may curtail investment in sustainability and conservation and poverty may increase pressure on natural resources.

\section{Ecosystems and Biodiversity}

There has been some evidence that wildlife has benefited from noise reductions and lesser human activity during the lockdowns of 2020 (Chowdhury and Chakraborty, 2021), but the economic downturn is hurting ecosystems where budgets for the management of protected areas are being cut. Due to limited monitoring of these protected areas and limited revenue from tourism the incidence of poaching is increasing in several countries, such as India (Saeed et al., 2020), as well as some countries in Africa (Roth, 2020) ${ }^{7}$ and South-East Asia (Briggs, 2020). A UNEP COVID-19 update (United Nations Environment Program, 2020b) details the decline in revenue from great ape tourism in Rwanda, which has been halted due to fears that humans could transmit the virus to the animals. Many protected areas use the income generated from tourism to

${ }^{7}$ Financial Times, 2-3 May, 2020. 
fund law enforcement, biomonitoring and staff salaries. Several months without tourism revenue has pushed many protected areas into a financial crisis. The release of staff and the suspension of law enforcement can easily lead to an increase in poaching and encroachment, firstly because there is little law enforcement, and secondly because community members have lost their income and have few other alternatives (Lindsey et al., 2020). Primate sanctuaries and rescue centres are also affected. Despite being closed to tourism, animals must still be fed and operations cannot simply be stopped. All these developments have a negative effect on activities associated with the green economy.

The problems are not confined to protected areas controlled or managed by the state but extend to community-managed areas, where the effects could be even more severe as they often have no state/tax revenue (Lindsey et al., 2020). Populations that depend on these areas are being hit hard, workers are losing their jobs (ibid). Behavioural changes in the very communities that were protecting wildlife and engaged in its conservation may become part of the problem if alternative employment and income opportunities are not found. There have been some signs, such as in Tamil Nadu, India that wild animal hunting has increased to fill gaps in income and the availability of meat (Sathishkumar and Rajan, 2020).

An African Union policy brief (African Union, 2020) reports that lockdowns will increase wildlife poaching. Many wildlife management authorities in Africa are semi-autonomous, largely relying on revenue from the tourism industry. However, an unprecedented decline in the number of international visitors is reducing revenue (Lindsey et al., 2020). Conservation in many places depends upon tourism revenue (Buckley, 2020). Many wildlife trusts will lose significant funding, further pushing communities into protected areas in search of livelihoods. Meanwhile, there are a growing number of calls to ban the trade and consumption of wildlife globally because of evidence that suggests COVID-19 originated in wild bats (Global Wildlife Conservation 2020). However, the links between wildlife, health, gender equality and the environment are complex (Keesing et al., 2010; Ostfeld, 2010; United Nations Environment Programme, 2020a) and bans could have unintended consequences for rural communities (see Section on Environmental Compliance Measures).

The African Union also reports the postponement and in some cases outright cancellation of many sustainable forest management activities (African Union, 2020). Another concern is that forest products will be seen as a means of recovery from the economic downturn created by COVID-19. Governments may resort to licensing extractive industries on public lands to raise the desperately needed financial resources to support socioeconomic development after the pandemic (Buckley, 2020). Deforestation of the Amazon, which soared in 2019 under the Bolsonaro administration, accelerated further in 2020 as South America battled the pandemic. In April, 405 square kilometres of rainforest wilderness was razed, an area almost four times the size of Paris. The Brazil space research agency reports this to be an increase of 64 per cent from April 2019. Deforestation further impacts indigenous people living in those areas, where there is poor access to health care facilities, especially for indigenous women seeking access to sexual and reproductive services, the elderly and for those with underlying illnesses.

Despite all these negative effects, there are also some positives. In Outamba Kilimi National Park, Sierra Leone, the rate of illegal timber harvesting has plummeted to zero, due to the drop in international demand. However, this situation must be carefully monitored, since local enterprises may take advantage of the lull to restock their timber yards with illegal logs in anticipation of the end of the pandemic (Inveen, 2020).

\section{Ecosystems Supporting Agri-Food Systems}

In addition to providing habitat for biodiversity, ecosystems support food and energy sectors that contribute to human health, livelihoods, and wellbeing. The provision of these ecosystem services are also being impacted by the pandemic. Examples are biofuel, rice production, and fisheries.

\section{Biofuel Demand}

Less demand for all fuels, including biofuels, owing to falling demand for transportation and lower oil prices has reduced demand and prices of feed stocks (Schmidhuber and Qiao, 2020). Biofuels contribute to powering transportation systems, but they also drive conversion of land use to biofuel crops. The fall in travel associated with the pandemic should also reduce biofuel demand and thus the incentive to clear land for growing fuel crops, but so far, there is no evidence that this has changed the pressure on forest clearance. The question of what happens to land that was used for biofuel production merits further investigation.

\section{Rice Production}

UN agencies have highlighted the adverse effect of COVID-19 on rice production and exports (United Nations Environment Programme, 2020c; Food and Agriculture Organization of the United Nations, 2020d). Pandemic-induced panic buying has encouraged some rice exporting countries to impose bans on exports, which has affected importing countries. Meanwhile, extended lockdowns in major rice producing countries have delayed the acquisition of inputs like fertilizers and seeds by local farmers (Esiobu, 2020). Restrictions on the movement of farm labourers could affect planting and harvesting, reducing future yields (World Bank, 2021). These supply disruptions will increase prices. Price surges disproportionately harm poorer households, for which rice is a staple and accounts for a significant proportion of monthly spending.

\section{Commercial and Subsistence Fisheries}

Fisheries have also suffered mixed impacts from the pandemic. A drop in demand has hurt commercial fisheries but may improve wild fish stocks in the short term (Food and Agriculture Organization of the United Nations, 2020e). Commercial fisheries may also suffer labour shortages and transportation disruption (Marschke et al., 2021). Studies show that in island countries and coastal areas, people who are unemployed may turn to fishing for food and income, increasing pressure on near-shore fish stocks. The pandemic may also exacerbate unregulated and unreported small-scale fishing in some areas, while in other areas 
the drop in demand may increase poverty in fishing communities (Bennett and Robinson, 2000).

\section{Pollution}

COVID-19 has been linked to harmful emissions in air, water and the land. Although these impacts do not directly implicate agriculture or food systems, they have important economic, health and social consequences. They also point to potential measures that can be applied in the agricultural sector and for food systems as part of rebuilding better, as discussed later.

\section{Air Emissions}

Emissions of nitrogen dioxide $\left(\mathrm{NO}_{\mathrm{x}}\right)$ and particulate matter $(\mathrm{PM})$ have declined notably across many countries (Berman, 2020). $\mathrm{NO}_{\mathrm{x}}$ satellite measurements of air quality for China, South Korea, Italy, Spain, France, Germany, Iran, and the United States (early epicentres of the virus) all show reductions from 20 to 40 per cent in $\mathrm{NO}_{\mathrm{x}}$ at times during the first half of 2020. On particulate matter, a study focused on China reported a 35 per cent reduction in $\mathrm{PM}_{2.5}$ (Shi and Brassuur, 2020) while the reduction in India was estimated to be 43 per cent for $\mathrm{PM}_{2.5}$ and 16 per cent for $\mathrm{NO}_{\mathrm{x}}$ (Sharma et al., 2020).

Reductions in PM concentrations have not been observed throughout the world. The European Environment Agency reports that although $\mathrm{NO}_{\mathrm{x}}$ concentrations have declined across the continent, a consistent reduction has not yet been observed across European cities (EEA, 2020). This is likely due to the fact that the main sources of this pollutant are more varied. In Europe, they include the combustion of fuel for heating residential, commercial and institutional buildings, as well as industrial activities. A significant fraction of particulate matter is also formed in the atmosphere from reactions of other air pollutants, including ammonia, which, in Europe is typically emitted by the application of agricultural fertilizers in the spring. Unfortunately, reductions in $\mathrm{NO}_{\mathrm{x}}$ have coincided with increases in surface ozone. An analysis of China noted that the decline in $\mathrm{PM}_{2.5}$ has been accompanied by an increase in concentrations of secondary pollutant surface ozone in the country of 150-200 per cent (Shi and Brassuur, 2020). Similarly, ozone concentrations in India have increased by 16 per cent (Sharma et al., 2020). This increase is probably a direct consequence of the declines in $\mathrm{NO}_{\mathrm{x}}$ on the presence of volatile organic compounds, since photochemical reactions between these two pollutants can result in higher ozone levels when $\mathrm{NO}_{\mathrm{x}}$ concentrations decline.

Changes in emissions of these harmful pollutants could significantly reduce premature mortality and morbidity, as well as losses from absenteeism. ${ }^{8}$ Links between concentrations of these pollutants and these health and work-related impacts at the global level are well documented (World Bank and Institute for Health Metrics and Evaluation, 2016) but there is not as yet an evaluation of the gains in terms of lives saved or reduced health and absenteeism costs associated with the current reductions.

${ }^{8}$ Given the reductions in output and demand for labor due to the virus, the effect on absenteeism will not be as important as it is under normal conditions.
Air pollution and higher concentrations of these pollutants have been linked to increased hospitalization and death from COVID-19 infection. New research has found that long-term exposure to air pollution may be "one of the most important contributors to fatality caused by the COVID-19 virus" around the world (Ogen, 2020). The study examined COVID-19 fatalities in four European countries that have been hit hard by the virus (Germany, France, Italy and Spain). It found 78 per cent of deaths occurred in just five regions in northern Italy and Spain. These regions had the highest concentrations of nitrogen dioxide $\left(\mathrm{NO}_{2}\right)$, a pollutant harmful to human respiratory systems. Moreover, the geography of these regions meant they also suffered from downward air pressure, which can prevent the dispersal of airborne pollutants. The findings of another recent study on the United States are similar: an analysis of 3,080 counties found that even a small increase in long-term exposure to air pollution could have a significant impact on the severity of COVID-19 symptoms (King, 2020). It suggests that lowering the average amount of airborne PM in Manhattan by just $1 \mu \mathrm{g}$ over the past 20 years could have led to 248 fewer deaths from the disease so far.

In addition to weakening our respiratory systems and making us more susceptible to COVID-19, air pollution might also be functioning as a vector for transmission for the virus. Scientists in Italy have detected coronavirus on particles of air pollution, which could, they believe, help the virus spread (Setti et al., 2020). However, these findings are preliminary.

The third link between COVID-19 and air quality relates to increased exposure to indoor air. The increase in the number of people remaining indoors as a result of the coronavirus pandemic makes managing indoor air pollution even more important. In developing countries, there are also emissions from the combustion of wood and coal inside homes. The Stockholm Environment Institute notes that in many developing countries, COVID-19-related measures requiring people to stay indoors and at home could increase exposure to indoors emissions. For example, exposure to air pollution among members of households who spent more time at home and use coal for cooking in Accra, Ghana, was twice as high as members who spent more time outside (SEI, 2020). Globally, three billion people still cook using unclean fuels and technologies leading to household air pollution further undermining their health. According to the WHO, "3.8 million people a year die prematurely from illness attributable to the household air pollution caused by the inefficient use of solid fuels and kerosene for cooking." Exposure is particularly high amongst women and young children who spend the most time near the domestic hearth, further reducing their immunity against zoonotic diseases including COVID-19 (World Health Organization, 2018).

\section{Access to Water}

In many communities around the world, a lack of a clean water supply and adequate sanitation deprives people of their most basic protections against the spread of the virus. This means that where handwashing is limited and waterborne diseases are already common COVID-19 could spread more easily (United 
Nations Environment Programme, 2020d). This aspect is also related to gender (United Nations Children's Fund, 2016). In many parts of the world, women and girls spend hours every day fetching water or waiting in crowded queues for water vendors, potentially increasing their risk of exposure to the virus. Their health and consequently their wellbeing could be further compromised if they struggle with these tasks because they are ill or have to care for people who are sick.

\section{Climate Change \\ GHG Emissions}

The International Energy Agency (IEA) estimates that global GHG emissions fell by about 8 per cent in 2020 due to contractions in demand for travel, transport and energy (International Energy Agency, 2020a). The UNEP Emissions Gap Report in 2019 estimated that to limit global warming to $1.5^{\circ} \mathrm{C}$, emissions would need to continue to fall by 7.6 per cent on average every year for the next 10 years (United Nations Environment Programme, 2019). These figures show the scale of the challenge we face in order to reduce GHG emissions.

There is also some evidence of a rebound effect, whereby this fall in emissions may be reversed in the extremely short term, partly as fear of infection makes people avoid public transport and switch to private vehicles with higher per capita emissions (a trend already partly observed in China). A similar reversal was observed after the 2008 crises. In April, 2020 when most countries were in lockdown, fossil fuel emissions were 17 per cent lower compared to the comparable 2019 figure (Le Quéré et al.,). However, the easing of restrictions has reduced this figure to just 5 per cent below the 2019 average and emissions in China have already rebounded to pre-pandemic levels (Integrated Carbon Observation System, 2021). As such, any fall in emissions due to the pandemic should be seen as temporary.

\section{Deforestation and Land Clearing}

FAO has argued that COVID-19 could increase widespread forest loss (Food and Agriculture Organization of the United Nations, 2020c). The CEO of Conservation International notes, "poaching and deforestation in the tropics have increased since COVID-19 restrictions came into force around the world, according to recent reports from Conservation International field offices", stressing that "a surge in agricultural expansion and illegal mining has accelerated forest loss in Brazil and Colombia” (Price, 2020). Preliminary evidence suggests that this is due to the reduced presence of government, policing organizations and NGOs in areas prone to illegal logging (Amador-Jimenez et al., 2020; Fair 2020). The links between the pandemic, enforcement of landclearing prohibitions and demand for land for food and fuel crops are complex and merit further investigation.

\section{Compound Human Health Impacts}

Diet-related health conditions appear to increase the mortality and morbidity of people who become infected with COVID-19. Just as air pollution may worsen infection rates and symptoms, non-communicable diseases (NCDs) like diabetes, heart disease and obesity have been linked to increased rates of infection, hospitalization, intensive care and death (Popkin et al., 2020).
Studies from Mexico, China and the United States have identified a connection between NCDs and the severity of COVID-19 infections (Azarpazhooh et al., 2020; Hernandez-Galdamez et al., 2020; Popkin et al., 2020). These compound morbidities are highlighted here because of the relationship between food systems and NCDs (Global Panel on Agriculture and Food Systems for Nutrition, 2016; Branca et al., 2019). It appears that healthier diets and the consequent lower incidence of NCDs could increase global resilience to COVID-19. Researchers have noted that tackling hunger and obesity requires a food systems approach (Steiner et al., 2020). Poor access to nutritious foods and the availability of inexpensive, high-calorie foods are associated with an increasing prevalence of NCDs globally. The connection between obesity and the severity of the pandemic provides further evidence for the urgent need for systemic improvements to food systems but is also an area where further research is required.

\section{COPING STRATEGIES AND THEIR IMPACTS}

Strategies are classified in this section under the following headings: monetary and fiscal stimuli; international aid and transfers; targeted support for agriculture; and targeted support for the environment.

\section{Response Through Monetary and Fiscal Stimuli}

The fiscal and monetary stimulus provided by governments as part of the global response to the pandemic has been unprecedented. Globally, in late 2020 the level of fiscal stimulus stood at approximately $\$ 11.7$ trillion as of September 2020, equivalent to nearly 14 per cent of global GDP (International Monetary Fund, 2020a). Fiscal support packages cover a wide range of measures that aim to replace lost household income and business revenues. They include easing or delaying payment obligations for taxes, utilities, rents and servicing debt (International Bank for Reconstruction and Development and World Bank, 2020). As of June 2020, the G20 countries were estimated to be providing $\$ 7.6$ trillion in fiscal support, equivalent to 11.2 per cent of their combined GDP for 2019. Of this sum, $\$ 4.1$ trillion has supported direct government spending, $\$ 2.6$ trillion for credit enhancements and $\$ 0.8$ trillion for tax relief (Segal and Gerstel, 2020). Several central banks have also loosened their monetary policy in the wake of the pandemic (International Monetary Fund, 2021). In most advanced economies, this has brought already low interest rates close to or below zero (Organisation for Economic Co-operation and Development, 2020a). Countries have also implemented extraordinary measures to ease tight credit markets by purchasing corporate debt. This approach follows in the footsteps of the financial crisis of 2008 and marks the second time major economic problems in the private sector have been tackled by a massive increase in public debt. 
Policymakers in emerging market and developing economies (EMDEs) have also used a range of monetary and fiscal measures to respond to the pandemic. In terms of monetary policy, they have supported the flow of credit, with several central banks sharply lowering interest rates and some complementing this with asset purchase programmes similar to those in advanced economies. In terms of fiscal policy, most EMDEs have announced fiscal policy support to confront the immediate health crisis and save lives, limit the scale of the economic contraction and accelerate the eventual recovery. At least three-quarters of EMDEs have increased funding for health care systems to expand testing and hospital capacity. Fiscal support has targeted the expansion of the coverage of social protection, including wage subsidies to protect jobs, cash transfers to households and increased access to unemployment benefits. Measures have also been implemented to ensure continued access to critical public services for vulnerable groups, including low-income households and the elderly (Argentina, Indonesia, Pakistan, the Philippines and Russia). Lastly, several countries have supported strained food systems through subsidies for inputs and cash transfers for food purchases (Organisation for Economic Co-operation and Development, 2020c; ONE n.d.; World Trade Organization, 2020b).

However, in some of the worst affected EMDEs, the fiscal response is constrained by the insufficient tax base and the lack of borrowing potential. In India the pandemic led to a significant contraction in tax revenues, causing the fiscal deficit for 2020-21 to balloon much higher than the budgeted 3.5 per cent. ${ }^{9}$ This limits the scope of government support and highlights the need for access to additional resources and to make public spending more efficient. Many developing and low-income countries are likely to face fiscal constraints as a result of high existing debt-toGDP ratios and the risk of inflationary pressure (Institute of International Finance, 2020). India, for example, has put together a 20 trillion Rupee ( $\$ 266$ billion) relief package, which is among the largest in the world and amounts to roughly 10 per cent of the country's GDP.

\section{Response Through Aid Transfers and Debt Relief}

Specific funds for poor countries to address COVID-19 include:

- Lending of up to \$150-160 billion from the World Bank, particularly for efforts to support vulnerable populations in client countries. $^{10}$

- The IMF has doubled access to its urgent facilities (Rapid Credit Facilityand Rapid Financing Instrument), allowing it to meet around $\$ 100$ billion of demand for financing. The

${ }^{9}$ https://theprint.in/economy/pandemic-pushes-indias-fiscal-deficit-to-9-5-in2020-21-estimated-at-6-8-in-2021-22/595806/ ; https://www.businesstoday.in/ current/economy-politics/govt-keeps-expenses-check-amid-covid-19-spendingapril-oct/story/423404.html

${ }^{10} \mathrm{https} / / /$ www.worldbank.org/en/news/press-release/2020/04/17/world-bankimfspring-meetings-2020-development-committee-communique
IMF has also offered immediate relief for servicing debts to 29 countries under its revamped Catastrophe Containment and Relief Trust, as part of its response to help address the impact of the COVID-19 pandemic.

- The European Union is making $€ 15$ billion available to help poor countries (particularly those with weak health care) fight the coronavirus epidemic and assist with the long-term economic recovery. ${ }^{11}$

- The G20 countries have agreed to suspend debt servicing on around $\$ 11$ billion of official bilateral credit to poorer countries. The IMF, the World Bank and the G20 have also called for private-sector creditors to replicate this measure, which could add a further $\$ 7$ billion of relief. Individual countries are also ramping up aid programmes for COVID-19.

While the amounts involved are clearly substantial, they must be considered in the context of the size of the crisis and the impact it will have on international aid in general. It is probable that COVID-support will drive overall reductions in global aid. ${ }^{12}$ Furthermore, emergency support will also shift the focus away from other development programmes. ${ }^{13}$ Global official development assistance levels could drop sharply by around $\$ 25$ billion by 2021, with the prospect of a protracted economic recession causing donors to reallocate their external budget to domestic spending and revival. ${ }^{14}$ This would amount to about 16 per cent of total official development assistance for 2019. In other words, spending in response to the pandemic may not result in additional net resources for developing countries.

Similarly, shift in budgets towards acute health could see a reduction in support for environmental protection and agriculture. There is already some evidence of less funding for the environment as stated in the previous section.

Furthermore, many investments have not been designed to address persistent underlying inequalities. In support of gender mainstreaming efforts in countries responses, the UN InterAgency Network on Women and Gender Equality (IANGWE) has published guidelines for integrating gender equality in the implementation of the UN framework for the socioeconomic response to COVID-19; and UNDP and UN Women have published a "COVID-19 Global Gender Response Tracker", which monitors policy measures enacted by governments worldwide to tackle the COVID-19 crisis, and highlights responses that have integrated a gender lens. The tracker which is still a work-in-progress shows that in July 2020, of the measures taken in response to COVID pandemic, only $42 \%$ are gender-sensitive. The tracker, includes 2,500 measures across over 206 countries to examine government measures taken in response to COVID-19 with a gender lens. The measures are

\footnotetext{
${ }^{11} \mathrm{https} / / /$ www.euractiv.com/section/development-policy/news/eu-announces-e15 billion-to-fight-virus-in-developing-countries/

${ }^{12} \mathrm{https}$ //devinit.org/resources/how-aid-changing-covid-19-pandemic/ ${ }^{13} \mathrm{https} / / /$ www.un.org/development/desa/en/news/sustainable/sustainabledevelopment-goals-report-2020.html

${ }^{14} \mathrm{https} / / /$ devinit.org/resources/coronavirus-and-aid-data-what-latest-dac-datatells-us/
} 
spread across three areas: those that tackle violence against women and girls, support unpaid care, and strengthen women's economic security.

\section{Support for Agriculture and the Environment in Responses to COVID-19}

As noted, the bulk of fiscal support has taken the form of cash transfers and additional resources for health services. The IMF Policy Tracker for COVID-19 cites a few examples of fiscal policies specifically targeting the agricultural sector but none focused on the environment. ${ }^{15}$ Of those that target the agrifood system in general very few pay attention to the environmental aspects of food production and consumption. The support mentioned for Afghanistan, Bangladesh and Nigeria are partial exceptions. ${ }^{16}$ Some other examples of national interventions to support agriculture and the environment are detailed below.

\section{Support for Agricultural Inputs}

The FAO recommends four measures to ensure supply of agricultural inputs: reduce farmer income uncertainty; support digitization of input markets; ease movement restrictions for procuring ag inputs; maintain government support for investment in ag inputs (Food and Agriculture Organization of the United Nations, 2020g). Some countries have heeded this advice. In India, the national relief package includes the provision of 300 billion rupees ( $\$ 4.5$ billion) of additional emergency working capital funding for small and marginal farmers to meet post-harvest spring (Rabi) and current autumn (Kharif) requirements. Several countries, including Angola, Haiti, Kyrgyzstan, Liberia and Senegal, are providing similar financial assistance, supported in part by agencies like the World Bank to address the reduction in access to finance among farmers (World Bank, 2020b).

\section{Support to Develop Local Supply Chains}

Transport problems have caused delays to the provision of inputs and migrant labour has become less accessible. These transport problems were caused by lockdowns and COVID-19 related travel restrictions which impacted the free movement of vehicles. ${ }^{17}$ In response, communities are developing local supply chains with some support from governments. In India, the Mayurbhanj District Administration launched the "Mayur fresh on wheels" initiative, with small vans delivering vegetables to people's houses with the slogan "Stay at home, eat safe". The initiative cuts out intermediaries by promoting farm-to-door delivery. India has also implemented the Farmers' Produce Trade and Commerce (Promotion and Facilitation) Ordinance

\footnotetext{
${ }^{15}$ https://www.imf.org/en/Topics/imf-and-covid19/Policy-Responses-toCOVID-19

${ }^{16}$ https://www.imf.org/en/Topics/imf-and-covid19/Policy-Responses-toCOVID-19

${ }^{17}$ https://www.iea.org/articles/changes-in-transport-behaviour-during-the-covid19-crisis
}

2020, which will promote barrier-free trade and commerce between and inside states of farm produce outside the physical premises of official markets.

In other countries, local initiatives are supporting direct market linkages between sellers and consumers. For example, vegetable supply bases around cities in China are ensuring smooth supplies of produce despite lockdowns (Food and Agriculture Organization of the United Nations, 2020b). In Kenya, the World Bank is providing $\$ 1$ billion through a development policy financing facility that will support significant reforms and deregulation in the agricultural sector. This includes facilities to allow farmers to buy inputs such as fertilizers and seeds electronically using vouchers on their mobile phones. However, the scheme has been criticized by advocates of local food systems for promoting the seeds and fertilizers of multinational companies at the expense of local supply chains. ${ }^{18}$

\section{Freer Movement of Trade}

These measures are in addition to others that seek to ensure global supply chains remain open and function efficiently. Net food importers face dangerous supply risks (Giordano and Ortiz de Mendívil, 2020). A deficit in its domestic maize supply had led Kenya to import maize from Uganda. However, since April, mandatory coronavirus tests for drivers at the border between the two states have seen queues of lorries stretching up to $30 \mathrm{~km} .{ }^{19}$ After some countries moved to restrict exports of food products, ${ }^{20}$ a powerful consortium of WTO member states (including the United States, China and the European Union) issued a joint statement on April 22, 2020 discouraging export restrictions and noting that they could lead to food insecurity. Its signatories committed not to impose export restrictions and to supporting WTO research and dialogue to ensure the function of agri-food supply chains (Food and Agriculture Organization of the United Nations, 2020a).

\section{Cash Support Programmes for Informal Workers}

As many as 84 countries have introduced or adapted social protection programmes; this includes 97 targeted cash transfer schemes, though only 10 countries, mainly in Latin America, specifically targeted informal workers. The amounts ranged from $\$ 39$ in Colombia to $\$ 153$ in Thailand. They were mostly one-off payments, except in Brazil with a monthly payment for three months (Food and Agriculture Organization of the United Nations, 2020b).

\section{Food Support Programmes}

Some countries have also provided specific support in the form of free or subsidized food and some public bodies are proactively

\footnotetext{
${ }^{18}$ https://www.oaklandinstitute.org/blog/world-bank-covid-19-assistance-kenyabenefits-multinational-agribusiness-agrochemical

${ }^{19} \mathrm{https} / / /$ www.one.org/africa/about/policy-analysis/covid-19-tracker/countrydeep-dives/

${ }^{20}$ https://public.tableau.com/profile/laborde6680\#!/vizhome/

ExportRestrictionsTracker/FoodExportRestrictionsTracker
} 
providing free meals. For instance, in India several women's selfhelp groups have mobilized to fill gaps in the provision of masks and sanitizers and in Delhi, free lunch and dinner are served at all local government night shelters (World Bank, 2020a).

Several countries have announced policies to address the disruption to school meals or food supplies to supplement cash transfers. The Government of Colombia has guaranteed the continuity of the provision of food to schoolchildren under its flagship school meals programme. It also plans food packages for 250,000 elderly people who are not receiving the corresponding cash transfer. In countries such as Afghanistan where such programmes are not in place, the government and development partners are using community development programmes, providing assistance to grain banks and supporting the distribution of food, as well as other necessities, to people in need, at the community level. ${ }^{21}$ In Pakistan, over 18,000 households (mainly female-headed) will receive support to develop kitchen gardens, small-scale livestock rearing and farming. ${ }^{22}$

South Africa provides an innovative example of "spontaneous venturing", with local supply chains (small informal shops and redeployed tourism staff) used for the humanitarian distribution of food parcels, linking emergency food aid to maintaining rural communities that rely on biodiversity and the benefits it provides as their main source of livelihood.

\section{Environmental Compliance Measures}

The environmental policy measures most directly related to COVID-19 target the spread of zoonotic diseases from wild animals. $^{23}$ China has outlawed the hunting for food and consumption of terrestrial wild animals, reinstating previous legislation designed to prevent the spread of viruses from animal species. ${ }^{24}$ It is not clear how many other countries have introduced restrictions on wild meat but there is considerable pressure to do so by government agencies, civil society and international organizations. The United Nations Convention on Biological Diversity calls on countries to help prevent future pandemics by better controlling all types of wildlife markets. However, their widespread bans can have unintended consequences, affecting low-income rural communities that depend upon wild animal hunting. For example, the Ebola crisis and the subsequent ban on the wide meat trade and markets across West and Central Africa resulted in unemployment for thousands of women, who are the primary traders of wild meat (Bonwitt et al., 2018). ${ }^{25}$

\footnotetext{
${ }^{21}$ https://www.worldbank.org/en/topic/poverty/brief/poverty-and-distributionalimpacts-of-covid-19-potential-channels-of-impact-and-mitigating-policies ${ }^{22} \mathrm{https} / /$ www.worldbank.org/en/topic/agriculture/brief/food-security-andcovid-19

${ }^{23}$ It is important to recognize that the source of the current pandemic is not yet confirmed. Nonetheless, linkages to animals (including wild and domesticated animals) are being investigated and there are influenza strains that can be transferred from domesticated animals such as pigs. See https://www. sciencemag.org/news/2020/06/swine-flu-strain-human-pandemic-potentialincreasingly-found-pigs-china.

${ }^{24}$ https://www.cifor.org/feature/covid-19-and-wild-meat/

${ }^{25}$ https://www.research.ox.ac.uk/Article/2020-04-16-the-covid-19-response-andwild-meat-a-call-for-local-context
}

India is one of the countries whose COVID-19 relief package has addressed environmental issues, with 60 billion rupees $(\$ 860$ million) of funding for employment related to forest management and soil and moisture conservation works. Kenya is another example and the Government has set aside two billion shillings (\$18.6 million) for community wildlife conservation affected by the fall in tourism. ${ }^{26}$

Many of the greatest impacts of COVID-19 on the environment and food systems will come from the policy measures taken by countries and international agencies to mitigate the pandemic and recover from the crisis, and whether or not these measures account for all environmental, gender, and socioeconomic impacts. Fiscal constraints have limited-and will increasingly limit-the capacity to implement support measures, especially in lowand middle-income countries. The next section uses these examples and lessons from the sustainable development agenda to look forward to how countries can build back better.

\section{LESSONS FROM COPING WITH COVID-19 AND THE WAY FORWARD}

The outbreak of COVID-19 and the fast global spread of the virus created a need for rapid response from governments all over the world. Strengthening health care systems and mitigating the economic impacts of the measures taken to contain the virus were packaged in several budgetary aid measures at both national and international level. Because of the unique situation and the urgency of the measures, states did not follow one grand design but had to readjust spending based on the latest developments and needs. In the following section we draw first lessons from the action taken by governments (as of end of August 2020).

\section{Lessons From the Measures Taken So far}

The measures in the previous section raise five important messages. First, while significant resources are being allocated to tackling the crisis, there are still areas where support must be scaled up or strengthened, especially to address undernutrition and food insecurity ${ }^{27}$ and associated, gender-related, socioeconomic factors. The UN World Food Programme has warned the international community that the world could face a huge food crisis and is lobbying for more investment in food aid. ${ }^{28}$ Even in wealthy countries, the rise in the use of food banks $^{29}$ can be partly explained by insufficient cash provision from the state. While emergency funding will help address the increase in food insecurity, it is not enough. FAO has publicly

\footnotetext{
${ }^{26} \mathrm{https}$ //www.nation.co.ke/kenya/news/what-is-in-it-for-you-in-uhuru-sstimulus-package-306398

${ }^{27}$ https://www.africanews.com/2020/05/14/coronavirus-africa-covid-19-coulddeepen-food-insecurity-malnutrition-in-africa/

${ }^{28} \mathrm{https}$ ///www.reuters.com/article/us-wfp-aid-idUSKBN26Y1S4

${ }^{29} \mathrm{https}$ ///www.nytimes.com/2020/04/08/business/economy/coronavirus-foodbanks.html
} 
raised awareness on the COVID-19 related challenges for African food systems. ${ }^{30}$

Second, the support packages being implemented are very much concentrated on short-term relief and the limited fiscal resources of most developing countries mean it is unclear how long they can continue. Given the second wave of the pandemic and persistent infection rates in many of these countries, the outlook could be extremely challenging, since fiscal room for manoeuvre is even more limited. This implies the need for more sustained international support in 2021 and possibly even after the COVID-19 threat has subsided to ensure a sustainable and equitable food system.

Third, there is a real concern that focusing on COVID-19 fiscal measures risks less resources for sustainable development in general and the crowding out of other important programmes that target the SDGs in 2021 and beyond. A report by Development Initiatives has flagged a potential fall in official development assistance of $\$ 25$ billion in 2021 (Development Initiatives, 2020). It is too early to assess how much the budgetary spending on COVID-19 will impact the achievement of the SDGs. Further research will be needed to monitor how the bail-out packages have contributed to achieving 'fewer people living in extreme poverty, less gender inequality, a healthier natural environment and more resilient societies' (UN Secretary General, March 2020).

Fourth, there has been a panoply of measures to support the agri-food sector, ranging from emergency financial support to farmers to more structural support for local supply chains; and new support measures are being launched based on short-terms needs in different countries. Going forward it will be critical to ensure that the right signals are sent to agents throughout the food sector to ensure its long-term recovery. Emergency relief must be more consistent with long-term objectives for sustainability, resilience, equity and gender equality.

Lastly, the measures have so far mostly ignored linkages to the environment, including the need to prevent further loss and degradation of habitats, which can facilitate the animal-tohuman transmission associated with the spread of zoonotic diseases such as COVID-19. This has to be addressed.

\section{The Way Forward}

The ongoing investments in programmes initiated to respond to COVID-19 are a clear indicator that the support initiated at the beginning of the pandemic will need country specific follow-up and will need to be strengthened in areas where they have proved inadequate. Key to any program will be the need to monitor the different impacts of the pandemic. Particularly important will be the impacts on the agrifood system and the environment. While country experiences have a lot in common, they also have many differences. These need to be taken into account in designing measures and that in turn will need careful tracking of the evidence.
As the disruptions in production that occurred during 2020 begin to affect food prices, more resources will be required to prevent undernutrition and food insecurity, ensure that local food supply systems function efficiently and protect the ecosystems that underpin the whole agri-food system. At the same time, it is also important to move from crisis intervention in the early phases of the global pandemic to a longer-term strategy of how to build back better. To be sure, the effects of the pandemic will be present for a long time, through lower investment, the erosion of human capital and declines in global trade and supply linkages. Taking these lasting impacts into account, it is critical that the recovery addresses both the economic, social and the environmental challenges that lie ahead. It should be possible, as the title of this article suggests, to build back better, by taking advantage of positive changes in behaviour during the crises to change the way in which we travel, produce and consume food, and use our environmental resources.

Building Back Better means rethinking the paradigm of aid and development assistance. The pandemic has shown that national borders are irrelevant to global issues like health, food security and sustainability. Rather than following traditional approaches to international development, the path forward should be for global development that relies upon multi-scaler analyses and identifies problematic dynamics between larger and smaller and richer and poorer countries (Oldekop et al., 2020). The path should also prioritize support for companies and agencies for a resilient and economically-just recovery.

The way forward comprises three parts: measures to be taken immediately, over the next six to nine months; shortterm measures, covering the next year; and deeper changes in the medium term that alter human behaviour and the structures that engender production and consumption to meet the SDGs. The proposals set out here complement the United Nations' framework for urgent socio-economic support to countries and societies in the face of COVID-19 (United Nations, 2020) and further develop the UNEP 10 Principles for Recovery. ${ }^{31}$

\section{Immediate Measures}

In line with the evolution of the pandemic in 2021 and beyond, the current measures will need to be maintained and even strengthened in areas where they are weak. Loss of income of people having been negatively affected by lockdowns remains a problem that prevents adequate access to food, people living in poverty struggle to isolate (Brown et al., 2020); health services are under pressure and resources to protect the environment are declining. These issues must be addressed urgently. The problems are greater in more unequal societies. COVID-19 is also showcasing that already existing inequalities have been increased by the pandemic. As the development economist Jeffery Sachs notes, "high inequality undermines social cohesion, erodes public trust, and deepens political polarization, all of which negatively affect governments' ability

${ }^{31}$ https://www.greengrowthknowledge.org/sites/default/files/downloads/resource/ SustainableInfrastructure-PrinciplesforRecovery.pdf
${ }^{30} \mathrm{https} / /$ timesofindia.indiatimes.com/world/rest-of-world/fao-calls-forimmediate-investment-to-sustain-africas-agriculture-post-covid-19/articleshow/ 76179325.cms 
and readiness to respond to crises". ${ }^{32}$ (Sachs, 2020). The crisis is not hitting all people in the same way despite the fact that all humans are susceptible to the virus.

In the agri-food sector, the most pressing issues are ensuring the supply of inputs (including labour) and addressing difficulties in the transportation of food inside countries. The challenges of access to food, transportation of food to markets and maintaining food supply on informal markets are described by affected people in real time $e^{33,34}$ Even in Africa, a continent with a relatively high level of self-sufficiency, only a fifth of food is eaten by the families that grow it. The rest moves down long supply chains, via lorries, processors and wholesale markets. Those who have land can depend on it for their own needs, but rural households living in poverty buy almost half of their food and a lack of stock in markets is also affecting supply. ${ }^{35}$ There have been major supply chain disruptions in many developing countries, especially in sub-Saharan Africa. Action is needed to improve networks for the transportation of food $^{36}$ that minimize loss and waste, with simultaneous action needed to develop local (urban and periurban) food production.

Given the restrictions on movement, a shortage of labour to work the land can be expected to cripple food systems if not addressed. In general, low-income countries employ higher shares of labour for primary production, leaving them more exposed to direct disruptions in the labour supply, including the labour available to individual farmers. The same holds for labour-intensive production: there are various examples of how production of fruit and vegetables and meat and dairy products have already been adversely affected by labour shortages caused by the pandemic (Schmidhuber et al., 2020). Action is needed to facilitate the movement of workers in the agri-food sector so that demands for their services can be better satisfied while taking measures to prevent the spread of COVID-19 among farm workers by improving working conditions.

Transmission in food processing workplaces has been causing problems. Some of the world's worst outbreaks of COVID-19 have been at meat processing plants owned by multinational corporations in Brazil, Canada, Germany, Spain and the United States. Over 10,000 plant workers have fallen ill in the United States and some have even died. ${ }^{37}$ Seafood processing plants are also hotspots, for example in Ghana, where an outbreak at a tuna canning plant owned by Thai Union was responsible for a tenth of the country's COVID-19 cases in May $2020 .^{38}$ Action is

\footnotetext{
${ }^{32}$ https://www.project-syndicate.org/commentary/inequality-fuels-covid19mortality-by-jeffrey-d-sachs-2020-06

${ }^{33} \mathrm{https} / / /$ medium.com/enabling-sustainability/video-diaries-from-nairobi-phaseii-navigating-food-insecurity-in-times-of-the-covid-19-pandemic-1efd016b965b

${ }^{34} @$ CovidFoodFuture

${ }^{35}$ https://www.economist.com/middle-east-and-africa/2020/04/23/the-race-tofeed-africa-during-a-pandemic

${ }^{36} \mathrm{https} / / /$ openknowledge.worldbank.org/handle/10986/34080

${ }^{37}$ https://www.businessinsider.in/international/news/almost-12000-meatpackingand-food-plant-workers-have-reportedly-contracted-covid-19-at-least-48-havedied-/articleshow/75633860.cms

${ }^{38} \mathrm{https}$ //www.undercurrentnews.com/2020/05/12/thai-union-ghana-cannerylinked-to-over-500-covid-19-cases-in-country/
}

needed to improve health and safety conditions in workplaces with a high risk of infection.

\section{Actions in the Short Term}

In parallel to immediate measures, governments are planning recovery packages for 2021 and beyond. Fiscal recovery from previous crises has tended to be carbon-intensive and pay little heed to environmental concerns. ${ }^{39}$ For example, the financial crisis caused $\mathrm{CO}_{2}$ emissions to fall by 1.44 per cent in 2009; however, the following year, they increased by 5.13 per cent, much higher than the pre-crisis rate. ${ }^{40}$ The International Energy Agency is monitoring the COVID-related decline in global $\mathrm{CO}_{2}$ emissions and states that the year 2020 saw a total drop of around $6 \%$. This was the largest annual decline since World War II, around two billion tons of greenhouse gases have been kept out of the sky. However, in December after the economy grew again, emissions were on the rise again and rose to a level higher than in December2019 ${ }^{41}$ (International Energy Agency 2020b).

To restart the economy, governments usually turn to sectors where investment can easily be made, often in carbon-intensive sectors, such as construction and airlines. A recent analysis of 17 major economies finds that 30 per cent of total announced stimulus will flow to sectors with an adverse impact on climate change, biodiversity or pollution. ${ }^{42}$ To avoid this, specific attention must be paid to different dimensions of the recovery that decouple economic activity from carbon emissions and biodiversity loss. There is a risk that recession could reduce investment in sustainability and that increases in poverty could induce behavioural change to cheap, short-term benefits, which must be avoided. Future research will have to analyse carefully if and how incentives to support recovery have led to a decoupling of growth and emissions. Best examples of recovery without increasing again the emission of $\mathrm{CO}_{2}$ should be used to describe a pathway to building back better.

The OECD notes that, at the very least, measures taken for recovery should conform to a "do no harm" criterion with respect to the environment (Agrawala et al., 2020). However, we should expect more from governments and measures should actively advance the SDGs. Environmental economists have identified three key no-cost policies that would support progress towards several of the SDGs and provide incentives for long-term sustainable development: fossil fuel subsidy swaps, irrigation subsidy swaps and a carbon tax to benefit the tropics (Barbier, 2020). ${ }^{43}$

\footnotetext{
${ }^{39}$ Peters, G., Marland, G., Le Quéré, C. et al. Rapid growth in $\mathrm{CO}_{2}$ emissions after the 2008-2009 global financial crisis. Nature Clim Change 2, 2-4 (2012). https:// doi.org/10.1038/nclimate1332

${ }^{40} \mathrm{http}: / /$ www.globalcarbonatlas.org/en/CO2-emissions

${ }^{41} \mathrm{https} / /$ www.iea.org/articles/global-energy-review-co2-emissions-in-2020

${ }^{42} \mathrm{https} / / / \mathrm{www} . v i v i d e c o n o m i c s . c o m / w p-c o n t e n t / u p l o a d s / 2020 / 06 / 200605-G r e e n-$ Stimulus-Index-1.pdf

${ }^{43} \mathrm{~A}$ fossil fuel subsidy swap would fund clean energy investments and the promotion of renewable energy in rural areas instead of supporting coal, oil and natural gas. Irrigation subsidies could be redesigned to improve water supplies, sanitation and wastewater infrastructure. Finally, a levy could be placed on fossil fuels to fund natural climate solutions in tropical countries.
} 
Natural capital investment for ecosystem resilience and regeneration (including the restoration of carbon-rich habitats and climate-friendly agriculture) have also been identified as having a long-run multiplier and a strongly positive impact on climate (Hepburn et al., 2020). Other promising avenues include clean energy infrastructure, clean connectivity infrastructure (e.g., low-carbon mobility), general research and development spending, clean energy research and development spending, and spending on education.

Environmental clean-up, investment in sustainable agriculture, safeguarding natural resources and improving energy efficiency generally have positive stimulus effects in the short run, as well as positive environmental effects in the longer run. Programmes that support these dual objectives in the energy sector include energy efficiency measures in buildings (weatherproofing) and in agriculture, which could yield significant cost savings and also be relatively labour intensive. Similarly, upgrading power transmissions systems could reduce the loss of energy. Other programmes include those that target congestion reduction, sustainable and resilient food systems and energysaving changes in cities. A recent UNEP policy brief outlines many of these "green-economy" options (United Nations Environment Program 2020e). ${ }^{44}$ Disappointingly, however, green measures account for less than 0.2 per cent of the total stimulus spending to counter the effects of COVID-19 by the world's 50 largest economies so far, ${ }^{45}$ despite evidence from the International Energy Agency that a focus on green-economy recovery options could save nine million jobs per year for the next 3 years. ${ }^{46}$

Regarding agriculture, there is an urgent need to rapidly rethink how we produce, process, market, handle and consume our food, as well as how we dispose of waste. This is the essence of a food systems approach to building back better-evaluating all links along the value chain following the concept of a eco-agri-food system. ${ }^{47}$ These issues are discussed further in the next section on mid-term measures. In the short term, countries must ensure that relief and stimulus packages reach the most vulnerable, including meeting the liquidity needs of small-scale food producers and rural businesses. ${ }^{48}$

Special attention must be paid to water management. A critical priority area will be preparing for potentially significant unplanned irrigation withdrawals-often used to increase short-run agricultural productivity-ensuring they do not withdraw too much water from aquifers, lakes and rivers. ${ }^{49}$ Building back better means constructing more resilient water, sanitation and hygiene systems that will deliver these fundamental services, taking into account the hydrological

\footnotetext{
${ }^{44}$ https://greenfiscalpolicy.org/policy_briefs/unep-policy-brief-on-building-backbetter-role-of-green-fiscal-policies/

${ }^{45} \mathrm{https} / / / \mathrm{www}$.bloomberg.com/features/2020-green-stimulus-clean-energy-future/

${ }^{46} \mathrm{https} / / /$ www.iea.org/reports/sustainable-recovery

${ }^{47}$ http://teebweb.org/wp-content/uploads/2018/10/Layout_synthesis_sept.pdf

${ }^{48} \mathrm{https} / / /$ www.un.org/sites/un2.un.org/files/sg_policy_brief_on_covid_impact_ on_food_security.pdf

${ }^{49}$ FAO. 2020. The State of Food and Agriculture 2020. Overcoming water challenges in agriculture. Rome.
}

uncertainties under climate change and growing water scarcity and pollution. In developing countries, there is significant potential to improve the efficiency of certain water infrastructure, in terms of reducing illicit extraction and incentivizing water-efficient agricultural practices. Such improvements can be made by simply upgrading existing infrastructure, which is typically labour intensive. Moreover, this can be done at relatively short notice.

The potential of green investments is huge. The International Resources Panel notes that a 60-80 per cent improvement in energy and water efficiency in sectors such as construction, agriculture, food, industry and transport could deliver cost savings of \$2.9-3.7 trillion per year by 2030, generating investment of $\$ 900$ billion and $9-25$ million jobs. ${ }^{50}$ Nonetheless, access to financing for such investment, especially where it also addresses other environmental and social goals, remains a challenge.

Another important aspect of the response to COVID-19 is reducing the potential for future pandemics. Animal-to-human transmission is the source of 75 per cent of infectious diseases and livestock rearing and wildlife trade are both significant drivers of global biodiversity loss (Taylor et al., 2001). The harvesting, transport and trade of wild meat and the intensive rearing of livestock have both been linked to the emergence and spread of zoonotic diseases. ${ }^{51}$ The likelihood of zoonotic diseases like COVID-19 and Ebola increases with habitat destruction, human encroachment on wildlife and current patterns of unregulated and illegal wild meat trade and consumption and wildlife trafficking. ${ }^{52}$ Biodiversity experts warn of even more deadly outbreaks in the future unless habitat destruction is halted.

Following the COVID-19 outbreak, there are growing calls to ban the trade and consumption of wildlife globally. However, the links between the consumption of wild meat, health and the environment are complex. Wild meat is an important financial backstop in parts of Africa, Asia, Latin America and the Arctic, in particular when harvests are poor or when agricultural commodity prices fluctuate, and particularly for women. If alternative sources of food and income are not provided for those who need it, bans on the trade and consumption of wild meat could result in malnutrition among the young and most vulnerable or push the trade underground, thus aggravating contributing factors to the spread of disease (May et al., in press). ${ }^{53}$ Such bans could also undermine a valuable incentive for communities to continue to protect wildlife.

\section{Actions in the Medium Term}

While recognizing the immense challenges the world faces, the discourse on the post-COVID future is mostly positive about the

\footnotetext{
${ }^{50}$ https://www.resourcepanel.org/sites/default/files/documents/document/media/ building_resilient_societies_after_the_covid-19_pandemic_-_key_messages_ from_the_irp_-_12_may_2020.pdf

${ }^{51}$ https://wedocs.unep.org/handle/20.500.11822/32285

${ }^{52} \mathrm{https} / / /$ www.unenvironment.org/resources/report/preventing-future-zoonoticdisease-outbreaks-protecting-environment-animals-and

${ }^{53} \mathrm{https}$ ///www.scidev.net/asia-pacific/opinions/covid-19-wild-meat-ban-deprivesforest-dwellers/
} 
prospects of building back better. The basis for this optimism is the changes in behaviour observed during the crises. There has been rapid adaptation to remote working and improvements in technology, which has the potential to reduce energy use and GHG emissions (Hook et al., 2020). As economies reopen, we may see a partial return to the pre-crisis normal but some behaviour will also change permanently. ${ }^{54}$ One speculative estimate is that up to one-third of the global workforce will continue to work remotely, at least on a part-time basis. ${ }^{55}$ The other reason to be optimistic is the strong public support for a positive change in direction, including in the corporate sector (The Economist, 2021).

It is essential to build on these positive forces for a better future. The extent to which behavioural adaptations become embedded after the pandemic will depend on policy choices during the recovery period and the extent and severity of lockdown measures. Moreover, in a rapidly changing external environment, the resilience of institutions and the economy to future shocks must be at the centre of the transition in order to increase the ability to function effectively under a range of shocks and stressful situations, especially in food systems.

\section{Driving Changes in Food Systems}

The task for agriculture and food systems in the years to come is huge: providing food security for a population projected to reach 10 billion in 2050 . The need to transform food systems was clear before the pandemic struck. ${ }^{56}$ This article has shown the additional challenges COVID-19 has created for food systems and how they have influenced the pandemic-from its suspected zoonotic origins to the compound health complications of obesity and NCDs.

Feeding a growing human population in ways that minimize harm to biodiversity is imperative to prevent the emergence of another zoonotic disease like COVID-19 (Batini et al., 2020). While wild meat hunting and trade can threaten endangered species, a shift from wild meat to livestock also raises concerns for many conservationists about deforestation (Bennett and Robinson, 2000; United Nations Environment Programme and International Livestock Research Institute, 2020). Researchers estimate that replacing wild meat in the Congo Basin with livestock such as cattle would mean converting 25 million hectares of forest into pastureland. ${ }^{57}$ Additionally, it has to be considered that other sources of protein-such as pigs and chickens-are also highly implicated in zoonoses (Backhans and Fellström, 2012).

The question is what stimulus packages can help to implement better systems in this area? Building back better includes ensuring healthy diets, slashing food loss and waste, reducing GHG emissions to limit climate change and adapting to its

\footnotetext{
${ }^{54}$ https://www.bbc.com/news/business-54413214

${ }^{55} \mathrm{https}$ ://globalworkplaceanalytics.com/work-at-home-after-covid-19-ourforecast

${ }^{56}$ http://teebweb.org/wp-content/uploads/2018/10/Layout_synthesis_sept.pdf

${ }^{57}$ https://www.research.ox.ac.uk/Article/2020-04-16-the-covid-19-response-andwild-meat-a-call-for-local-context
}

inevitable impacts, reversing habitat loss, limiting animal-human disease transmission, developing rural areas to create jobs and to improve the livelihoods of people living in poverty, and maintaining ecosystem services, such as clean water and air, on a rapidly urbanizing planet. Factors such as unequal access to land tenure, financial resources and decision-making power can create economic stress in households, leaving women disproportionately exposed to climate-related food security risks (Nellemann et al., 2011). Securing land rights for local communities can help address these issues to some extent. Health, Education and Gender Equality are key developmental outcomes as well. By addressing these issues simultaneously, we are helping to prevent the future spread of zoonotic diseases and to build resilient, sustainable and healthy food systems. The complexity of these interrelated challenges is systematically analysed, e.g. by the OECD, arguing for a policy response for "building back better". 58

Tackling these challenges requires a systematic approach, as suggested by The Economics of Ecosystems and Biodiversity for Agriculture and Food (TEEB AgriFood) (The Economics of Ecosystems and Biodiversity (TEEB), 2018). Increasing food production without significant progress on reducing the environmental impacts of food systems is not sustainable in the long run. Estimates of the negative externalities of the food system amount to $\$ 12$ trillion a year, equivalent to about 8 per cent of global GDP in $2019 .{ }^{59}$ While we have yet to realize a comprehensive vision of the whole agri-food system, encompassing social equity and jobs, as well as health and environmental impacts, the steps needed to do so are becoming increasingly clear and momentum in this direction is growing. First steps of implementation of the TEEB AgriFood framework in the standard accounting system of food companies by trying to capture the positive and negative externalities of the eco-agri-food system reveals the potential of True Cost Accounting (TCA) as a tool to monitor and steer the transformation towards sustainability. ${ }^{60}$

The pandemic has also turned our attention to food supply chains. On the one hand, there is a concern that COVID-19 will reduce confidence in global food supply chains, which feed billions and have proven efficient and cost-effective. On the other, there is a growing interest in local supply chains and more environmentally friendly local foods. In practice, being closer does not always mean being greener: it also depends on how produce is grown and the inputs, including fossil-fuel based energy. We need a full life-cycle analysis along the lines proposed by the TEEB report to determine the most effective combination of local and global supply chains, recognizing that there is scope for both. ${ }^{61}$ Global supply chains should be used where favoured by comparative advantages, climate and economies of scale, while

\footnotetext{
${ }^{58} \mathrm{https}$ //oecd.org/coronavirus/policy-responses/building-back-better-asustainable-resilient-recovery-after-covid-19-52b869f5/

${ }^{59}$ https://www.foodandlandusecoalition.org/wp-content/uploads/2019/09/FOLUGrowingBetter-GlobalReport.pdf

${ }^{60} \mathrm{http}$ ///teebweb.org/our-work/agrifood/reports/measuring-what-matterssynthesis/

${ }^{61}$ http://teebweb.org/agrifood/
} 
local ones should be promoted where they can meet the demand more effectively and sustainably. ${ }^{62}$ In other words, support should be provided for a shift from tightly controlled value chains to more flexible business models that are resilient to the kinds of shocks food systems will face in the future. ${ }^{63}$ (The World Bank programme of e-vouchers for subsidies in Kenya cited earlier in this report is a good example.) Finally, given the inherent uncertainty around how food systems evolve, it is critical for developments in this area to be closely monitored in order to respond correctly.

\section{Protecting Habitats and Preventing the Degradation of Ecosystems}

The community of researchers and practitioners has long been aware of the loss of ecosystem services due to the degradation and loss of habitats and biodiversity. The current crisis has made the wider public more aware of these issues. The risk from zoonotic diseases is exacerbated by the destruction of habitats for wild animals and the overexploitation of these species. Arecently released scientific assessment from UNEP and the International Livestock Research Institute (ILRI) argued that unless countries take dramatic steps to curb zoonotic contagion, global outbreaks like COVID-19 will become increasingly common. ${ }^{64}$ We must acknowledge the interdependence of nature, humans and food systems, and evaluate the implications of wild and domestic animal consumption for food security, food sovereignty, sustainability and the risk of zoonotic diseases (May et al., in press). In this context, smart regulations and incentives for trade in and consumption of wild meat, combined with adequate measures to ensure compliance, would help achieve the second objective of the Convention on Biological Diversity: sustainable use of biodiversity. ${ }^{65}$

One proposal emerging from the crisis with an international implementation plan is called One Health-. It is an integrated approach that prevents and mitigates the threats at animal-human-plant-environment interfaces. ${ }^{66}$ This could represent a major contribution to bringing together a number of key players. The issues addressed by the One Health include ways to reduce the zoonotic risks posed by livestock and wild animals as well as reducing the consumption of meat, where appropriate, alongside changes to habitats and land use from agricultural conversion, while improving environmental surveillance. To work the approach must be designed and implemented in a broader systems context. Implementation should also include inviting stakeholders from public health, gender, biodiversity, climate and agrifood systems to develop common guidelines for national stimulus packages (Laurans et al., 2020). This would also capitalize on United Nations

\footnotetext{
${ }^{62}$ https://www.ft.com/content/d7a12d18-8313-11ea-b6e9-a94cffd1d9bf

${ }^{63} \mathrm{https} / / /$ oecd.org/coronavirus/policy-responses/building-back-better-asustainable-resilient-recovery-after-covid-19-52b869f5/

${ }^{64} \mathrm{https}$ ://www.unenvironment.org/news-and-stories/story/daily-covid-19-casesreach-new-high-new-report-examines-how-prevent-future

${ }^{65}$ https://www.cifor.org/knowledge/publication/5397/

${ }^{66} \mathrm{http}: / /$ www.fao.org/asiapacific/perspectives/one-health/en/
}

inter-agency working groups on biodiversity and health, as well as the One Health tripartite alliance.

SDG targets 15.1, 15.2 and 15.3 set clear objectives for reversing the loss and degradation of animal habitats. ${ }^{67}$ This shows the presence of an agenda for measures to reduce the risks of future pandemics. However, the problem is catalysing the action needed to achieve this. Given the enormous costs of the COVID-19 crisis, countries should invest in achieving these goals and in reducing the risk of future pandemics. Surveillance tools must be sharpened and mechanisms applied to regulate threats such as the illegal, unsustainable and unregulated trade in timber and wildlife and the use of toxic pesticides. This will require strong support for the post-2020 Global Biodiversity Framework. One of the lessons learned from COVID-19 pandemic is that more resources allocated to achieve these targets are needed and that governments must prioritize appropriate action.

\section{Promoting Low-Carbon Lifestyles}

We have noted the potential for a faster transition to a low-carbon economy and society, and the impetus derived from the pandemic. A key difficulty in implementing the transition to a resilient low-carbon society has been the issue of economic justice and social inequality, since people involved in carbon-intensive sectors could lose out from the transition, with a lack of immediate options for alternative livelihoods. The pandemic is also increasing economic and health inequality both within countries and between rich and poor countries. ${ }^{68}$ The impact on employment is more pronounced among people with lower incomes and lower education. Similarly, while debt has increased for low-income households, wealthier households are seeing an increase in savings. ${ }^{69}$

The implications of these factors on policies implemented in pursuit of a low-carbon economy mean that policymakers must be mindful of their distributional effects. One example is promoting remote working to reduce transport-related emissions. Research has shown that the share of work that can be done from home varies significantly for countries with different incomes: in urban areas, this share is only about 20 per cent in low-income countries compared with 40 per cent in high-income countries. Educational attainment, formal employment status and household wealth are positively associated with the possibility of working from home, reflecting the vulnerability of certain groups of workers (Gottlieb et al., 2020). This means that measures to encourage

\footnotetext{
${ }^{67}$ Target 15.1: By 2020, ensure the conservation, restoration and sustainable use of terrestrial and inland freshwater ecosystems and their services, in particular forests, wetlands, mountains and drylands, in line with obligations under international agreements. Target 15.2: By 2020, promote the implementation of sustainable management of all types of forests, halt deforestation, restore degraded forests and substantially increase afforestation and reforestation globally. Target 15.3: Take urgent and significant action to reduce the degradation of natural habitats, halt the loss of biodiversity and, by 2020 , protect and prevent the extinction of threatened species.

${ }^{68} \mathrm{https} / / /$ www.ifs.org.uk/publications/14879

${ }^{69} \mathrm{https} / / /$ www.imf.org/external/pubs/ft/fandd/2020/09/COVID19-and-globalinequality-joseph-stiglitz.htm
} 
working from home will need to be complemented with others to improve access to the infrastructure that makes this possible. A second policy that could reduce GHG emissions is buying locally, avoiding long-distance transport. While such a policy has the potential to reduce transport emissions, it could prove devastating for developing countries that export fresh produce, such as fruit, flowers and livestock products. Moreover, when all life-cycle emissions are taken into account, it may not actually reduce emissions. As such, food system investments should follow the results of life cycle assessments and economic impact analyses. Third, in light of the significant labour supply shock caused by the pandemic, it is important to note that green industries will not be able to hire unemployed workers unless there is a strong programme for retraining and relocation.

The measures described here add up to a substantial program of action, also with a large budget. Although the costs of these measures have not been worked out in detail, one comparison of the figures suggests that the cost of preventing further pandemics over the next decade by protecting wildlife and forests would be just 2 per cent of the estimated financial damage caused by COVID-19, proof that prevention is better than cure (Dobson et al., 2020).

\section{CONCLUSION}

The global sustainable development agenda has at its core promoting the resilience and sustainability of food systems via a framework of policies and measures. Strategies to achieve the 2030 agenda have to be designed so as to: i) account for environmental thresholds and trade-offs; ii) promote food security and healthy diets; iii) enhance and protect rural livelihoods; and iv) address the inequalities and injustices that have emerged during the crises and that will continue to prevail during the post-pandemic transition. To be sure, this is challenging, as thresholds are difficult to establish and compromises on trade-offs are hard to reach, but it can be made easier through better evidence.

Support will most certainly be needed from the International community, including the United Nations agencies to ensure effective implementation of this framework. One way of doing this will be to provide support to countries to monitor the environmental impacts of COVID-19. The effectiveness of

\section{REFERENCES}

African Union (2020). African Forests and the COVID-19 Pandemic. Policy Brief. Agrawala, S., Dussaux, D., and Monti, N. (2020). "What Policies for Greening the Crisis Response and Economic Recovery? Lessons Learned from Past Green Stimulus Measures and Implications for the COVID-19 Crisis," in OECD Working Paper No. 164 (Paris: OECD).

Amador-Jiménez, M., Millner, N., Palmer, C., Pennington, R. T., and Sileci, L. (2020). The Unintended Impact of Colombia's Covid-19 Lockdown on Forest Fires. Environ. Resource Econ. 76 (4), 1081-1105. doi:10.1007/s10640-02000501-5

Anand, S. S., Hawkes, C., de Souza, R. J., Mente, A., Dehghan, M., Nugent, R., et al. (2015). Food Consumption and its Impact on Cardiovascular Disease: Importance of Solutions Focused on the Globalized Food System. J. Am. recovery and stimulus packages should be measured against indicators for progress on the SDGs. Additionally, a United Nations agency could also take the lead in expanding the environmental dimensions of the One Health approach to improve the understanding of linkages and impacts when it comes to zoonotic diseases.

\section{AUTHOR CONTRIBUTIONS}

AM was the coordinating Lead Author for the paper. He reviewed the literature, contributed to writing it and responded to internal comments. JS contributed to the writing of the paper, review of the literature and response to internal comments. SH coordinated the project from which this study has been extracted. He also contributed to editing the paper. AM was the project director. $\mathrm{He}$ provided a lot of the materials and reviewed drafts of the paper. ST contributed materials for the paper, especially from India and reviewed drafts.

\section{ACKNOWLEDGMENTS}

This paper is the product of a UNEP project to investigate the links between COVID, the agri-food system and the environment. The authors acknowledge the contribution of all those working to understand the ramifications of this pandemic and their efforts to determine solutions for the welfare of our communities and environment. Special thanks are extended for comments and suggestions provided by: Doreen L. Robinson, Chief for Wildlife, UNEP Ecosystems Division; Sirini Withana, Economic and Trade Policy Unit, UNEP Economy Division; James Lomax, Food Systems and Agriculture Adviser, UNEP Ecosystems Division; Susan Mutebi-Richards, Gender Reviewer, Gender and Safeguards Unit, Policy and Programme Division; Jian Liu, Chief Scientist and Director, UNEP Science Division; Edward Barbier, University Distinguished Professor in the Department of Economics, Colorado State University, Senior Scholar in the School of Global Environmental Sustainability; Peter May, Professor titular CPDA/UFRRJ. Thanks are also due to three referees from the journal who made many suggestions that improved the paper.

Coll. Cardiol. 66 (14), 1590-1614. doi:10.1016/j.jacc.2015.07.050 Available at: https://www.sciencedirect.com/science/article/pii/S0735109715046215?via\% 3Dihub.

Azarpazhooh, M. R., Morovatdar, N., Avan, A., Phan, T. G., Divani, A. A., Yassi, N., et al. (2020). COVID-19 Pandemic and burden of Non-communicable Diseases: An Ecological Study on Data of 185 Countries. J. Stroke

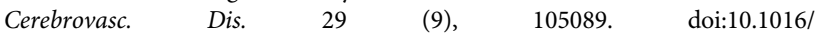
j.jstrokecerebrovasdis.2020.105089

Backhans, A., and Fellström, C. (2012). Rodents on Pig and Chicken Farms - a Potential Threat to Human and Animal Health. Infect. Ecol. Epidemiol. 2 (1), 17093. doi:10.3402/iee.v2i0.17093

Barbier, E. B. (2020). Greening the post-pandemic Recovery in the G20. Environ. Resource Econ. 76, 685-703. doi:10.1007/s10640-020-00437-w

Batini, N., Lomax, J., and Mehra, D. (2020). Why Sustainable Food Systems Are Needed in a post-COVID World. Available at: https://www.unenvironment. 
org/news-and-stories/story/why-sustainable-food-systems-are-needed-postcovid-world (Accessed October 9, 2020).

Bennett, E. L., and Robinson, J. G. (2000). "Hunting of Wildlife in Tropical Forests - Implications for Biodiversity and Forest Peoples (English)," in World Bank Environment Department Paper No. 76 (Washington, D.C.: World Bank).

Berman, R. (2020). The Dual Effects of COVID-19 Lockdowns on Air Quality. Available at: https://www.medicalnewstoday.com/articles/the-dual-effects-ofcovid-19-lockdowns-on-air-quality (Accessed October 9, 2020).

Bonwitt, J., Dawson, M., Kandeh, M., Ansumana, R., Sahr, F., Brown, H., et al. (2018). Unintended Consequences of the 'bushmeat Ban' in West Africa during the 2013-2016 Ebola Virus Disease Epidemic. Soc. Sci. Med. 200 (12), 166-173. doi:10.1016/j.socscimed.2017.12.028

Branca, F., Lartey, A., Oenema, S., Aguayo, V., Stordalen, G. A., Richardson, R., et al. (2019). Transforming the Food System to Fight Non-communicable Diseases. BMJ 364, 1296. doi:10.1136/bmj.1296

Briggs, H. (2020). Coronavirus: Fears of Spike in Poaching as Pandemic Poverty Strikes. Available at: https://www.conservation.org/blog/poaching-deforestation-reportedlyon-the-rise-since-covid-19-lockdowns (Accessed October 9, 2020).

Brown, C. S., Ravallion, M., and van de Walle, D. (2020). Can the World's Poor Protect Themselves from the New Coronavirus? NBER Working Papers No. 27200. Cambridge, Massachusetts: National Bureau of Economic Research, Inc.

Buckley, R. (2020). Conservation Implications of COVID19: Effects via Tourism and Extractive Industries. Biol. Conservation 247 (4), 108640. doi:10.1016/ j.biocon.2020.108640

Caruso, G. D., Cucagna, M. E., and Ladronis, J. (2021). The Distributional Impacts of the Reduction in Remittances in Central America in COVID-19 Times. Res. Soc. Stratification Mobility 71, 100567. doi:10.1016/j.rssm.2020.100567

Chowdhury, M. B., and Chakraborty, M. (2021). The Impact of COVID-19 on the Migrant Workers and Remittances Flow to Bangladesh. South Asian Surv. 28 (1), 38-56. doi:10.1177/0971523121995365

Dash, D. P., Sethi, N., and Dash, A. K. (2020). Infectious Disease, Human Capital, and the BRICS Economy in the Time of COVID-19. MethodsX 8, 101202. doi:10.1016/j.mex.2020.101202

Development Initiatives (2020). Coronavirus and Aid Data: What the Latest DAC Data Tells Us. Available at: https://devinit.org/resources/coronavirus-and-aiddata-what-latest-dac-data-tells-us/ (Accessed October 9, 2020).

Djiofack, C. Z., Dudu, H., and Zeufack, A. G. (2020). "Assessing COVID-19's Economic Impact in Sub-saharan Africa: Insights from a CGE Model," in COVID-19 in Developing Economies. Editors S. Djankov and U. Panizza (London: CEPR Press).

Dobson, A. P., Pimm, S. L., Hannah, L., Kaufman, L., Ahumada, J. A., Ando, A. W., et al. (2020). Ecology and Economics for Pandemic Prevention. Sci. 369 (6502), $379-381$.

EEA (2020). Air Quality in Europe. Report 09/2020. Copenhagen: European Environment Agency.

Espitia, A., Rocha, N., and Ruta, M. (2020). COVID-19 Ad Food Protectionism: The Impact of the Pandemic and Export Restrictions on World Food Markets. World Bank Policy Research Working Paper, 9253.

Esiobu, N. S. (2020). Does the Incidence of COVID-19 Pandemic Affect Rice Yield? Lessons from Southeast Nigeria. Recent Advances in Rice Research. doi:10.5772/ intechopen. 93744

Fair, J. (2020). COVID-19 Lockdown Precipitates Deforestation across Asia and South America. Available at: https://news.mongabay.com/2020/07/covid-19lockdown-precipitates-deforestation-across-asia-and-south-america/ (Accessed October 9, 2020).

Food and Agriculture Organization of the United Nations (2020d). Why Export Restrictions Should Not Be a Response to COVID-19: Learning Lessons from Experience with Rice in Asia and the Pacific. Available at: http://www.fao.org/ policy-support/tools-and-publications/resources-details/en/c/1287457/.

Food and Agriculture Organization of the United Nations (2020f). Agrifood Markets and Trade in the Time of COVID-19. Rome: FAO. doi:10.4060/ca8446en

Food and Agriculture Organization of the United Nations (2020a). Gendered Impacts of COVID-19 and Equitable Policy Responses in Agriculture, Food Security and Nutrition. Rome: FAO. Available at: http://www.fao.org/3/ ca9198en/CA9198EN.pdf.

Food and Agriculture Organization of the United Nations (2020b). Impact of COVID-19 on Informal Workers. Rome: FAO. Available at: http://www.fao.org/ 3/ca8560en/CA8560EN.pdf.
Food and Agriculture Organization of the United Nations (2016). Improving Food Systems for Nutrition and Health. Rome: Viale delle Terme di Caracalla. Available at: http://www.fao.org/3/a-i6066e.pdf.

Food and Agriculture Organization of the United Nations (2020e). Novel Coronavirus (COVID-19). Q\&A. Available at: http://www.fao.org/2019-ncov/ q-and-a/impact-on-fisheries-and-aquaculture/en/ (Accessed October 9, 2020).

Food and Agriculture Organization of the United Nations (2020g). Policy Responses to Keep Input Markets Flowing in Times of COVID-19. Rome: FAO. doi:10.4060/ca8446en

Food and Agriculture Organization of the United Nations (2020c). The Impacts of COVID-19 on the forest Sector: How to Respond? the Impacts of COVID-19 on the forest Sector: How to Respond? Available at: http://www.fao.org/3/ ca8844en/CA8844EN.pdf.

Food Security Portal (2020). COVID-19 Food Price Monitor. Available at: http:// tools.foodsecurityportal.org/COVID-19-food-price-monitoring (Accessed October 9, 2020).

Giordano, P., and Ortiz de Mendívil, C. (2020). How Trade Policy Can Help Avoid A Food Crisis under COVID-19. Banco Interamericano de Desarrollo. Retrieved from: https://publications.iadb.org/en/how-trade-policy-can-help-avoid-afood-crisis-under-covid-19.

Global Panel on Agriculture and Food Systems for Nutrition (2016). Food Systems and Diets: Facing the Challenges of the 21st Century. London: IFRI. Available at: https://www.ifpri.org/publication/food-systems-and-diets-facing-challenges21 st-century.

Goel, R. K., Saunoris, J. W., and Goel, S. S. (2020). "Supply Chain Reliability and International Economic Growth: Impacts of Disruptions like COVID-19," in CESifo Working Paper No. 8294 (Munich: CESifo). Available at: https://www. cesifo.org/en/cesifo/privacy-policy.

Gonzalez, S., and Aronczyk, A. (2020). Food and Frameworks. Available at: https:// choice.npr.org/index.html?origin=https://www.npr.org/2020/03/25/ 821593542/episode-984-food-and-farmworkers (Accessed October 9, 2020).

Gottlieb, C., Grobovšek, J., Poschke, M., and Saltiel, F. (2020). "Working from home: Implications for Developing Countries," in COVID-19 in Developing Economies. Editors S. Djankov and U. Panizza (London: CEPR Press). Available at: https://voxeu.org/content/covid-19-developing-economies.

Gupta, A., Zhu, H., Doan, M. K., Michuda, A., and Majumder, B. (2020). Economic Impacts of the COVID-19 Lockdown in a Remittance-Dependent Region. Am. J. Agric. Econ. 103, 466-485. doi:10.1111/ajae.12178

Headey, D., Heidkamp, R., Osendarp, S., Ruel, M., Scott, N., Black, R., et al. (2020). Impacts of COVID-19 on Childhood Malnutrition and Nutrition-Related Mortality. The Lancet 396 (10250), 519-521. doi:10.1016/S0140-6736(20)31647-0

Hepburn, C., O'Callaghan, B., Stern, N., Stiglitz, J., and Zenghelis, D. (2020). Will COVID-19 Fiscal Recovery Packages Accelerate or Retard Progress on Climate Change?. Oxford Rev. Econ. Pol. 36, S359-S381. doi:10.1093/oxrep/graa015

Hernández-Galdamez, D. R., González-Block, M. Á., Romo-Dueñas, D. K., LimaMorales, R., Hernandez-Vicente, I. A., Hernández-Vicente, I. A., et al. (2020). Increased Risk of Hospitalization and Death in Patients with COVID-19 and Pre-existing Noncommunicable Diseases and Modifiable Risk Factors in Mexico. Arch. Med. Res. 51 (7), 683-689. doi:10.1016/j.arcmed.2020.07.003

Hook, A., Court, V., Sovacool, B. K., and Sorrell, S. (2020). A Systematic Review of the Energy and Climate Impacts of Teleworking. Environ. Res. Lett. 15 (9), 093003. doi:10.1088/1748-9326/ab8a84

Institute of International Finance (2020). Global Debt Monitor. COVID-19 Lights a Fuse. Available at: https://www.iif.com/Portals/0/Files/content/Research/ Global\%20Debt\%20Monitor_April2020.pdf?.

Integrated Carbon Observation System (2021). Supplementary Data: Temporary Reduction in Daily $\mathrm{CO}_{2}$ Emissions during the COVID-19 Forced Confinement. Available at: https://www.icos-cp.eu/gcp-covid19 (Accessed October 9, 2020).

International Bank for Reconstruction and Development and World Bank (2020). Macro Poverty Outlook Country-By-Country Analysis and Projections for the Developing World. Washington, D.C: Spring. Available at: http://pubdocs. worldbank.org/en/312551567719790821/mpo.pdf.

International Energy Agency (2020a). Global Energy Review 2020. Paris: IEA. Available at: https://www.iea.org/reports/global-energy-review-2020/globalenergy-and-co2-emissions-in-2020.

International Energy Agency (2020b). Sustainable Recovery: World Energy Outlook Special Report. Paris: OECD Publishing. 
International Monetary Fund (2020b). Fiscal Monitor: Policies for the Recovery. Washington: FISCAL MONITOR.

International Monetary Fund (2020a). Policy Responses to COVID-19. Available at: https://www.imf.org/en/Topics/imf-and-covid19/Policy-Responses-toCOVID-19 (Accessed October 9, 2020).

International Monetary Fund (2021). World Economic Outlook Update. Washington DC: WORLD ECONOMIC OUTLOOK.

Inveen, C. (2020). Coronavirus Comes to rescue of Sierra Leone's Plundered Rosewood. Available at: https://www.reuters.com/article/us-healthcoronavirus-leone-logging/coronavirus-comes-to-rescue-of-sierra-leonesplundered-rosewood-idUSKBN21I1B0 (Accessed October 9, 2020).

Keesing, F., Belden, L. K., Daszak, P., Dobson, A., Harvell, C. D., Holt, R. D., et al. (2010). Impacts of Biodiversity on the Emergence and Transmission of Infectious Diseases. Nature 468, 647-652. doi:10.1038/nature09575

King, A. (2020). Linking Air Pollution to Higher Coronavirus Death Rates. Available at: https://www.hsph.harvard.edu/biostatistics/2020/04/linking-airpollution-to-higher-coronavirus-death-rates/ (Accessed October 9, 2020).

Laurans, Y., Rankovic, A., Chabason, L., Barchiche, D., Elouardighi, K., and Treyer, S. (2020). Quelles initiatives politiques internationales pour la prévention des maladies infectieuses d'origine zoonotique? [What International Policy Initiatives for the Prevention of Infectious Diseases of Zoonotic Origin?]. Paris: IDDRI. Available at https://www.iddri.org/fr/publications-etevenements/autre-publication/quelles-initiatives-politiques-internationalespour-la.

Le Quéré, C., Jackson, R. B., Jones, M. W., Smith, A. J. P., Abernethy, S., Andrew, R. M., et al. (2020). Temporary Reduction in Daily Global CO2 Emissions during the COVID-19 Forced Confinement. Nat. Clim. Chang. 10, 647-653. doi:10.1038/s41558-020-0797-x

Lindsey, P., Allan, J., Brehony, P., Dickman, A., Robson, A., Begg, C., et al. (2020). Conserving Africa's Wildlife and Wildlands through the COVID19 Crisis and beyond. Nat. Ecol. Evol. 4 (10), 1300-1310. doi:10.1038/ s41559-020-1275-6

Marschke, M., Vandergeest, P., Havice, E., Kadfak, A., Duker, P., Isopescu, I., et al. (2021). COVID-19, Instability and Migrant Fish Workers in Asia. Maritime Stud. 20 (1), 87-99. doi:10.1007/s40152-020-00205-y

May, P., Gebara, M. F., and Platais, G. (in press). Pandemics, Conservation and Human-Nature Relations.

Mbow, C., Rosenzweig, C., Barioni, L. G., Benton, T. G., Herrero, M., Krishnapillai, M., et al. (2019). "Food Security," in Climate Change and Land: An IPCC Special Report on Climate Change, Desertification, Land Degradation, Sustainable Land Management, Food Security, and Greenhouse Gas Fluxes in Terrestrial Ecosystems. Editors. P.R. Shukla, J. Skea, E. Calvo Buendia, V. Masson-Delmotte, and H.-O. Pörtner Available at: https://www.ipcc.ch/site/assets/uploads/2019/08/2f.Chapter-5_FINAL.pdf.

Minten, B., Habte, Y., Seneshaw, T., and Tesfaye, A. (2020). The Transforming Dairy Sector in Ethiopia. Available at: https://journals.plos.org/plosone/article? id=10.1371/journal.pone.0237456 (Accessed October 9, 2020).

Nandi, R., Nedumaran, S., Selvaraj, A., Datta Mazumdar, S., and Kumar, S. (2021). The COVID-19 Induced Disruptions across Groundnut Value Chain: Empirical Evidence from South India. Sustainability 13 (4), 1707. doi:10.3390/su13041707"

Nellemann, C., Verma, R., and Hislop, L. (2011). Women at the Frontline of Climate Change: Gender Risks and Hopes: a Rapid Response Assessment. Retrieved from: https://www.researchgate.net/search/publication? $\mathrm{q}=$ Women+at+the+Frontline+of+Climate+Change $\%$ $3 \mathrm{~A}+$ Gender+Risks+and+Hopes.

Ogen, Y. (2020). Assessing Nitrogen Dioxide (NO2) Levels as a Contributing Factor to Coronavirus (COVID-19) Fatality. Sci. Total Environ. 726, 138605. doi:10.1016/j.scitotenv.2020.138605

Oldekop, J. A., Horner, R., Hulme, D., Adhikari, R., Agarwal, B., Alford, M., et al. (2020). COVID-19 and the Case for Global Development. World Dev. 134, 105044. doi:10.1016/j.worlddev.2020.105044

ONE (n.d.). ONE Africa COVID-19 Tracker: Country Deep Dives. Available at: https://www.one.org/africa/about/policy-analysis/covid-19-tracker/countrydeep-dives/ (Accessed October 9, 2020).
Organisation for Economic Co-operation and Development (2020c). Agricultural Policy Monitoring and Evaluation. Available at: https://www.oecd-ilibrary.org// sites/5d209bd5-en/index.html?itemId=/content/component/5d209bd5-en\#.

Organisation for Economic Co-operation and Development(2020b). COVID-19 and the Food Agriculture Sector: Issues and Policy Responses. Available at: http://www.oecd. org/coronavirus/policy-responses/covid-19-and-the-food-and-agriculturesector-issues-and-policy-responses-a23f764b/ (Accessed October 9, 2020).

Organisation for Economic Co-operation and Development (2020a). Economic Outlook, June 2020. Paris: OECD. Available at: https://www.oecd.org/ economic-outlook/.

Ostfeld, R. S. (2010). Biodiversity Loss and the Rise of Zoonotic Pathogens. Clin. Microbiol. Infect. 15 (Suppl. 1), 40-43. doi:10.1111/j.14690691.2008 .02691

Oxfam Australia (2020). More people could die daily from COVID-19 linked hunger Than the virus itself: Oxfam. Available at: https://media.oxfam.org.au/ 2020/07/more-people-could-die-daily-from-covid-19-linked-hunger-than-thevirus-itself-oxfam/ (Accessed October 9, 2020).

Patrick, K. (2020). A Mile-Long Line for Free Food in Geneva, One of World's Richest Cities. Available at: https://www.nytimes.com/2020/05/30/world/ europe/geneva-coronavirus-reopening.html (Accessed October 9, 2020).

PBL Netherlands Environmental Assessment Agency (2014). How Sectors Can Contribute to Sustainable Use and Conservation of Biodiversity. CDB Technical Series No. 79. Available at: https://www.cbd.int/doc/publications/cbd-ts-79-en.pdf.

Popkin, B. M., Du, S., Green, W. D., Beck, M. A., Algaith, T., Herbst, C. H., et al. (2020). Individuals with Obesity and COVID-19: A Global Perspective on the Epidemiology and Biological Relationships. Obes. Rev. 21 (11), e13128. doi:10.1111/obr.13128

Price, K. (2020). Poaching, Deforestation Reportedly on the Rise since COVID-19 Lockdowns. Available at: https://www.conservation.org/blog/poachingdeforestation-reportedly-on-the-rise-since-covid-19-lockdowns (Accessed October 9, 2020).

Roth, A. (2020). Poachers Kill More Rhinos as Coronavirus Halts Tourism to Africa. Available at: https://www.nytimes.com/2020/04/08/science/ coronavirus-poaching-rhinos.html (Accessed October 9, 2020).

Sachs, J. D. (2020). How Inequality Fuels COVID 19 Deaths. Available at: https:// www.project-syndicate.org/commentary/inequality-fuels-covid19-mortality-byjeffrey-d-sachs-2020-06?barrier=accesspaylog (Accessed October 9, 2020).

Saeed, A., Sinha, N., Joshi, A. R., and Shishir, N. N. (2020). Coronavirus: With South Asia in Lockdown, Poachers Are Brazenly Killing Endangered Animals and Birds. Available at: https://scroll.in/article/963797/coronavirus-withsouth-asia-in-lockdown-poachers-are-brazenly-killing-endangered-animals-andbirds (Accessed October 9, 2020).

Sathishkumar, R., and Rajan, M. R. (2020). COVID-19: How Wildlife Hunting Increased in Tamil Nadu amid Lockdown. Available at: https://www. downtoearth.org.in/blog/wildlife-biodiversity/covid-19-how-wildlife-huntingincreased-in-tamil-nadu-amid-lockdown-71676 (Accessed October 9, 2020).

Schmidhuber, J., Pound, J., and Qiao, B. (2020). COVID-19: Channels of Transmission to Food and Agriculture. Rome: FAO. doi:10.4060/ca8430en

Schmidhuber, J., and Qiao, B. (2020). Comparing Crises: Great Lockdown versus Great Recession. Rome: FAO. doi:10.4060/ca8833en

Science Media Centre (2020). Expert Comments about Meat Processing Plants and Slaughterhouses and COVID-19 Outbreaks. Available at: https://www. sciencemediacentre.org/expert-comments-about-meat-processing-plants-andslaughterhouses-and-covid-19-outbreaks/ (Accessed October 9, 2020).

Segal, S., and Gerstel, D. (2020). Breaking Down the G20 COVID-19 Fiscal Response. Available at: https://www.csis.org/analysis/breaking-down-g20covid-19-fiscal-response-june-2020-update (Accessed October 26, 2020).

SEI (2020). COVID-19 Pandemic Raises New Questions about the Health Impacts of Air Pollution. Available at: https://www.sei.org/featured/covid-19pandemic-raises-new-questions-about-the-health-impacts-of-air-pollution/ (Accessed October 9, 2020).

Setti, L., Passarini, F., De Gennaro, G., Barbieri, P., Perrone, M. G., Borelli, M., et al. (2020). SARS-Cov-2RNA Found on Particulate Matter of Bergamo in Northern Italy: First Evidence. Environ. Res. 188, 109754. doi:10.1016/ j.envres.2020.109754Available at: https://www.medrxiv.org/content/10.1101/ 2020.04.15.20065995v2. 
Sharma, S., Zhang, M., Anshika, A., Gao, J., Zhang, H., and Kota, S. H. (2020). Effect of Restricted Emissions during COVID-19 on Air Quality in India. Sci. Total Environ. 728, 138878. doi:10.1016/j.scitotenv.2020.138878

Shi, X., and Brasseur, G. P. (2020). The Response in Air Quality to the Reduction of Chinese Economic Activities during the COVID-19 Outbreak. Geophys. Res. Lett. 47 (11), e2020GL088070. doi:10.1029/2020GL088070

Steiner, A., Aguilar, G., Bomba, K., Bonilla, J. P., Campbell, A., Echeverria, R., et al. (2020). Actions to Transform Food Systems under Climate Change. Wageningen: CGIAR Research Program on Climate Change, Agriculture and Food Security (CCAFS).

Tableau Public (2020). Food export Restrictions during the COVID-19 Crisis. Available at: https://public.tableau.com/profile/laborde6680\#!/vizhome/ ExportRestrictionsTracker/FoodExportRestrictionsTracker (Accessed October 9, 2020).

Taylor, L. H., Latham, S. M., and Woolhouse, M. E. J. (2001). Risk Factors for Human Disease Emergence. Phil. Trans. R. Soc. Lond. B 356 (1411), 983-989. doi:10.1098/rstb.2001.0888

The Economics of Ecosystems and Biodiversity (TEEB) (2018). Measuring what Matters in Agriculture and Food Systems: A Synthesis of the Results and Recommendations of TEEB for Agriculture and Food's Scientific and Economic Foundations Report. Geneva: UNEP. Available at: http://teebweb. org/our-work/agrifood/reports/measuring-what-matters-synthesis/.

The Economist (2020). The Race to Feed Africa during a Pandemic. Available at: https://www.economist.com/middle-east-and-africa/2020/04/23/the-race-tofeed-africa-during-a-pandemic (Accessed October 9, 2020).

The Economist (2021). The Rise of Working from Home. Special report: The future of work. Available at: https://www.economist.com/special-report/2021/04/08/ the-rise-of-working-from-home.

United Nations (2020). A UN Framework for the Immediate Socio-Economic Response to COVID-19. Available at: https://www.un.org/sites/un2.un.org/ files/un_framework_report_on_covid-19.pdf.

United Nations Children's Fund (2020). Tracking the Situation of Children during COVID-19. Available at: https://data.uniceforg/resources/rapid-situation-trackingcovid-19-socioeconomic-impacts-data-viz/ (Accessed October 9, 2020).

United Nations Children's Fund (2016). UNICEF: Collecting Water Is Often a Colossal Waste of Time for Women and Girls. Available at: https://www.unicef. org/press-releases/unicef-collecting-water-often-colossal-waste-time-womenand-girls (Accessed October 9, 2020).

United Nations Environment Programme and International Livestock Research Institute (2020). Preventing the Next Pandemic: Zoonotic Diseases and How to Break the Chain of Transmission. Nairobi: UNEP. Available at: https://www. unenvironment.org/resources/report/preventing-future-zoonotic-diseaseoutbreaks-protecting-environment-animals-and.

United Nations Environment Programme (2020c). COVID-19 Is Disrupting a Food Industry Already Thrown into Turmoil by Climate Change. Available at: https:// www.unenvironment.org/news-and-stories/story/covid-19-disrupting-foodindustry-already-thrown-turmoil-climate-change (Accessed October 9, 2020).

United Nations Environment Programme (2019). Emissions Gap Report 2019. Nairobi. Available at: https://www.unenvironment.org/resources/emissionsgap-report-2019.

United Nations Environment Programme (2020a). Human Rights, the Environment and Covid-19 Key Messages. Available at: https://www.unenvironment.org/resources/ report/human-rights-environment-and-covid-19-key-messages.
United Nations Environment Programme (2020d). UNEP Policy Brief on Building Back Better - Role of green Fiscal Policies. Available at: https:// greenfiscalpolicy.org/policy_briefs/unep-policy-brief-on-building-back-betterrole-of-green-fiscal-policies/ (Accessed October 9, 2020).

United Nations Environment Programme (2020b). What COVID-19 Means for Ecotourism. Available at: https://www.unenvironment.org/news-and-stories/ story/what-covid-19-means-ecotourism (Accessed October 9, 2020).

World Bank and Institute for Health Metrics and Evaluation (2016). The Cost of Air Pollution: Strengthening the Economic Case for Action. Washington, D.C.: World Bank. Available at: https://openknowledge.worldbank.org/handle/ $10986 / 25013$.

World Bank (2018). Decline of Global Extreme Poverty Continues but Has Slowed: World Bank. Available at: https://www.worldbank.org/en/news/press-release/ 2018/09/19/decline-of-global-extreme-poverty-continues-but-has-slowed-worldbank (Accessed October 9, 2020).

World Bank (2021). Food Security And COVID-19. Policy Brief. Available at: https://www.worldbank.org/en/topic/agriculture/brief/food-security-and-covid-19.

World Bank (2020a). Global Economic Prospects. Washington, D.C.: World Bank. doi:10.1596/978-1-4648-1553-9

World Bank (2020b). In India, Women's Self-Help Groups Combat the COVID-19 (Coronavirus) Pandemic. Feature Story. Available at: https://www.worldbank. org/en/news/feature/2020/04/11/women-self-help-groups-combat-covid19coronavirus-pandemic-india.

World Cancer Research Fund International (2014). The Link between Food, Nutrition, Diet and Non-communicable Diseases. London: World Cancer Research Fund. Available at: https://www.wcrf.org/sites/default/files/PPA NCD_Alliance_Nutrition.pdf.

World Food Programme (2020). WFP Chief Warns of Hunger Pandemic as COVID-19 Spreads (Statement to UN Security Council). Available at: https://www.wfp.org/news/wfp-chief-warns-hunger-pandemic-covid-19-spreadsstatement-un-security-council (Accessed October 9, 2020).

World Health Organization (2018). Household Air Pollution and Health. Available at: https://www.who.int/news-room/fact-sheets/detail/household-air-pollutionand-health (Accessed October 9, 2020).

World Trade Organization (2020b). Covid-19 and Agriculture: A Story of Resilience. World Trade Organization, 1-12. Retrieved from: https://www.wto.org/ english/tratop_e/covid19_e/agric_report_e.pdf.

World Trade Organization (2020a). WTO Report Finds Growing Number of export Restrictions in Response to COVID-19 Crisis. Available at: https://www. wto.org/english/news_e/news20_e/rese_23apr20_e.htm (Accessed October 9, 2020).

Conflict of Interest: The authors declare that the research was conducted in the absence of any commercial or financial relationships that could be construed as a potential conflict of interest.

Copyright (c) 2021 Markandya, Salcone, Hussain, Mueller and Thambi. This is an open-access article distributed under the terms of the Creative Commons Attribution License (CC BY). The use, distribution or reproduction in other forums is permitted, provided the original author(s) and the copyright owner(s) are credited and that the original publication in this journal is cited, in accordance with accepted academic practice. No use, distribution or reproduction is permitted which does not comply with these terms. 